NISTIR 7933

\title{
Requirements and Conformance Test Assertions for ANSI/NIST-ITL 1-2011 Record Type 18 - DNA Record
}

\author{
Fernando L. Podio \\ Dylan Yaga \\ Christofer J. McGinnis
}

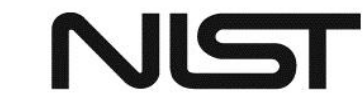

National Institute of Standards and Technology U.S. Department of Commerce 
NISTIR 7933

\section{Requirements and Conformance Test Assertions for ANSI/NIST-ITL 1-2011 Record Type 18 - DNA Record}

Fernando L. Podio Dylan Yaga

Christofer J. McGinnis

Computer Security Division Information Technology Laboratory

http://dx.doi.org/10.6028/NIST.IR.7933

May 2013

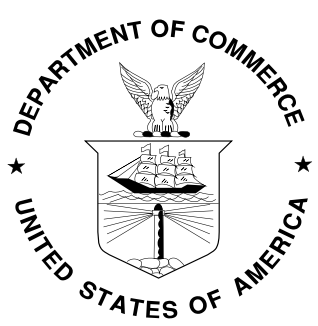

U.S. Department of Commerce Rebecca Blank, Acting Secretary

National Institute of Standards and Technology Patrick D. Gallagher, Under Secretary of Commerce for Standards and Technology and Director 
Certain commercial entities, equipment, or materials may be identified in this document in order to describe an experimental procedure or concept adequately. Such identification is not intended to imply recommendation or endorsement by NIST, nor is it intended to imply that the entities, materials, or equipment are necessarily the best available for the purpose.

There may be references in this publication to other publications currently under development by NIST in accordance with its assigned statutory responsibilities. The information in this publication, including concepts and methodologies, may be used by Federal agencies even before the completion of such companion publications. Thus, until each publication is completed, current requirements, guidelines, and procedures, where they exist, remain operative. For planning and transition purposes, Federal agencies may wish to closely follow the development of these new publications by NIST.

Organizations are encouraged to review all draft publications during public comment periods and provide feedback to NIST. All NIST Computer Security Division publications, other than the ones noted above, are available at http://csrc.nist.gov/publications.

\title{
Comments on this publication may be submitted to: biocts@nist.gov
}

\author{
National Institute of Standards and Technology \\ Attn: Computer Security Division, Information Technology Laboratory \\ 100 Bureau Drive (Mail Stop 8930) Gaithersburg, MD 20899-8930 \\ Email: biocts@nist.gov
}




\section{Reports on Computer Systems Technology}

The Information Technology Laboratory (ITL) at the National Institute of Standards and Technology (NIST) promotes the U.S. economy and public welfare by providing technical leadership for the Nation's measurement and standards infrastructure. ITL develops tests, test methods, reference data, proof of concept implementations, and technical analysis to advance the development and productive use of information technology. ITL's responsibilities include the development of technical, physical, administrative, and management standards and guidelines for the cost-effective security and privacy of sensitive unclassified information in Federal computer systems. This Interagency Report discusses ITL's research, guidance, and outreach efforts in computer security, and its collaborative activities with industry, government, and academic organizations.

\section{Abstract}

The Computer Security Division (CSD) of NIST/ITL develops conformance test architectures (CTAs) and test suites (CTSs) to support users that require conformance to selected biometric standards. Product developers as well as testing laboratories can also benefit from the use of these tools. This project supports the possible establishment of conformity assessment programs for biometrics and also supports NIST/ITL's Forensic Science Program by making conformance testing tools available that provide developers, users, and purchasers with increased levels of confidence in product quality and increases the probability of successful interoperability of biometrics and forensic data. One of the test tools is a CTA/CTS designed to test implementations of ANSI/NIST-ITL 12011 (AN-2011) "Data Format for the Interchange of Fingerprint, Facial \& Other Biometric Information" for selected Record Types based on twelve hundred test assertions previously developed. As part of the process associated with the extension of the first version of BioCTS for AN-2011, NIST/ITL/CSD's staff identified over two-hundred test assertions necessary to meet the conformance requirements for the AN-2011 Record Type 18- DNA Record. These test assertions are documented using the format specified in NIST Special Publication 500-295, "Conformance Testing Methodology for ANSI/NIST-ITL 1-2011, Data Format for the Interchange of Fingerprint, Facial \& Other Biometric Information (Release 1.0)".

\section{Keywords}

ANSI/NIST-ITL 1-2011, biometrics, conformance testing, conformance test architecture, CTA, CTS, BioCTS, conformance test suite, data interchange, DNA data, Record Type 18, test assertions, testing methodology

\section{Prologue}

The Computer Security Division (CSD) of NIST/ITL supports the development of biometric conformance testing methodology standards and other conformity assessment efforts through active technical participation in the development of biometric standards and associated conformance test architectures and test suites. NIST/ITL CSD develops these test tools to support users that require conformance to selected biometric standards and product developers interested in conforming to biometric standards by using the same testing tools available to users. Testing laboratories can also benefit from the use of these test tools. These efforts support the possible establishment of conformity assessment programs to validate conformance to biometric standards. This project supports NIST/ITL's Forensic Science Program by making available conformance test tools that 
provide developers, users, and purchasers with increased levels of confidence in product quality and increases the probability of successful interoperability of biometrics and forensic data.

NIST/ITL CSD has developed a number of Conformance Test Architectures (CTAs) and Test Suites (CTSs) designed to test implementations of biometric technical interfaces and data interchange formats. Previous work includes a CTS designed to test implementations of the ANSI INCITS 3582002 standard, the Biometric BioAPI specification [1], a CTS designed to test implementations of Patron Format A data structures Specified in ANSI INCITS 398-2008, Common Biometric Exchange Formats Framework (CBEFF) [2], a CTA called "CTA Beta 2.0" and CTS designed to test implementations of biometric data interchange formats developed by INCITS M1 ${ }^{1}$ [3], and a CTA/CTS designed to test implementations of selected Record Types of ANSI/NIST-ITL 1-2007, -Data Format for the Interchange of Fingerprint, Facial, \& Other Biometric Information - Part 1 [4].

NIST/ITL CSD released a set of conformance test tools under the label "BioCTS" in 2012 and early 2013. These tools include CTAs and CTSs designed to test implementations of biometric data interchange format standards developed by ISO/IEC JTC1/SC $37^{2}$ and selected PIV profiles ("BioCTS for ISO/IEC"), as well as selected Record Types within ANSI/NIST-ITL 1-2011 (AN2011) transactions ("BioCTS for AN-2011”) [5].

\section{Disclaimer}

Statements made in this paper should not be interpreted as standards, guidelines, best practices, or recommendations for specific changes to any other NIST publications.

\footnotetext{
${ }^{1}$ InterNational Committee for Information Technology Standards Technical Committee M1 - Biometrics

${ }^{2}$ International Standards Organization (ISO) and the International Electrotechnical Commission (IEC) Joint Technical Commission 1 - Information Technology/ Subcommittee 37 - Biometrics
} 


\section{Table of Contents}

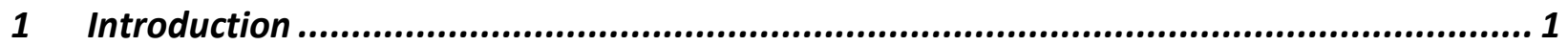

1.1 Conformance Testing to Biometric Standards ............................................................1

1.2 Requirements and Test Assertions for ANSI/NIST-ITL 1-2011........................................1

1.3 BioCTS for AN2011 - Conformance Test Software for AN-2011 .........................................1

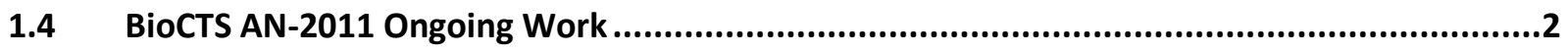

2 Test Assertions for AN-2011 Record Type 18 - DNA Record ...................................... 3

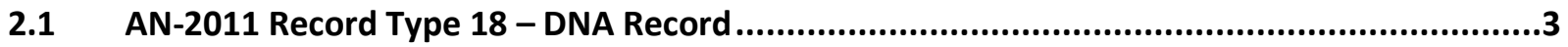

2.2 Record Type 18 Table of Requirement and Assertions...................................................

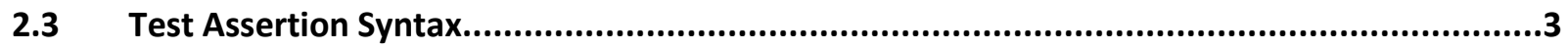

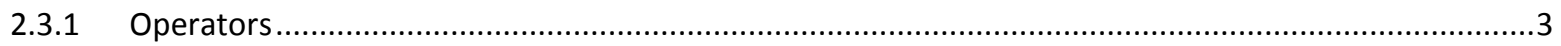

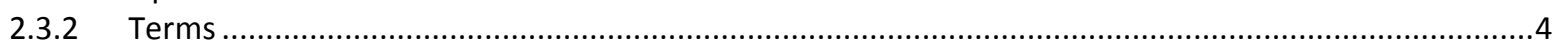

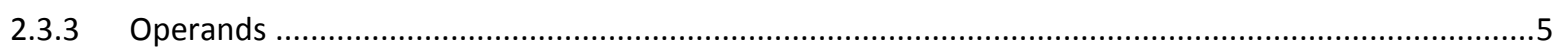

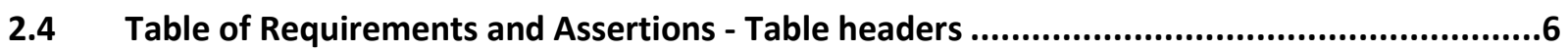

Annex A - References.............................................................................. 9

Appendix B - Record Type-18: DNA Record Requirements and Assertions ........................ 10

B.1 Record Type 18 - DNA Record Requirements and Test Assertions ...........................................10

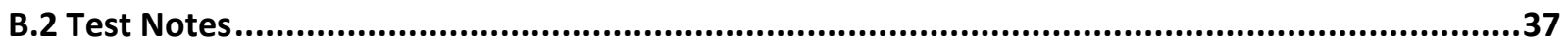

\section{List of Tables}

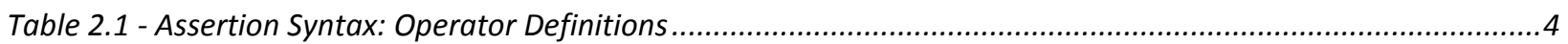

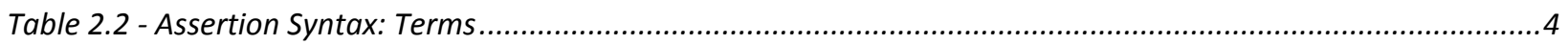

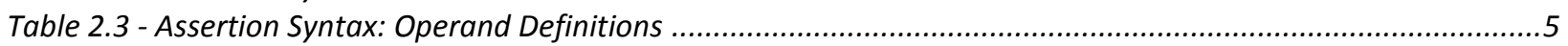

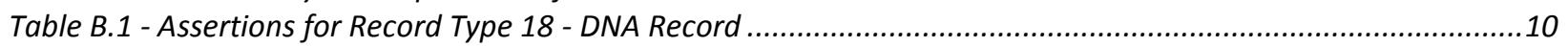




\section{Introduction}

\subsection{Conformance Testing to Biometric Standards}

The existence of biometric standards alone is not enough to demonstrate that products meet the technical requirements specified in the standards. Conformance testing captures the technical description of a specification and measures whether an implementation faithfully implements the specification. Conformance testing supports increasing levels of confidence in product quality and increases the probability of successful interoperability and data interchange. A conformance testing methodology developed in support of conformance testing, should include the conformance test requirements of a standard indicating what level of conformance testing is applicable to each requirement and should specify the conformance test assertions to be tested for the corresponding requirements. Test assertions are specifications for testing a conformance requirement in an Implementation Under Test in the form of software or procedural methods that generate the test results (also named test outcomes or test verdicts) used for assessment of the conformance requirement.

\subsection{Requirements and Test Assertions for ANSI/NIST-ITL 1-2011}

ANSI/NIST-ITL 1-2011 (AN-2011) is the latest version of the ANSI/NIST-ITL standard, and is specified in NIST Special Publication 500-290 [6]. This standard defines the content, format, and units of measurement for the electronic exchange of fingerprint, palmprint, plantar, facial/mugshot, scar, mark \& tattoo (SMT), iris, deoxyribonucleic acid (DNA), and other biometric sample and forensic information that may be used in the identification or verification process of a subject. The information consists of a variety of mandatory and optional items. This information is primarily intended for interchange among criminal justice administrations or organizations that rely on automated identification systems or use other biometric and image data for identification purposes.

NIST/ITL CSD developed a set of test assertions based on the requirements specified in AN-2011 to aid in the development process for the first version of an AN-2011 CTA/CTS. Over twelve hundred test assertions for selected Record Types were identified and documented as a set of tables in NISTIR 7806 to assist in CSD's development of BioCTS [7]. These tables of requirements and the associated test assertion syntax were later adopted as part of the conformance testing methodology documented in NIST Special Publication 500-295[8].

\subsection{BioCTS for AN2011 - Conformance Test Software for AN-2011}

The test assertions documented in NIST Special Publication 500-295 are implemented in BioCTS for AN2011 [9], which tests components of AN-2011 transactions associated with the following sections and Record Types of the AN-2011 standard:

- Section 5: Data Conventions

- Section 7: Information Associated with Several Record Types

- Section 8.1 Record Type-1: Transaction information record

- Section 8.4 Record Type-4: Grayscale fingerprint image

- Section 8.10 Record Type-10: Facial, other body part and SMT image record

- Section 8.13 Record Type-13: Friction-ridge latent image record 
- Section 8.14 Record Type-14: Fingerprint image record

- Section 8.15 Record Type-15: Palm print image record

- Section 8.17 Record Type-17: Iris image record

- Annex B: Traditional Encoding

Transactions under test can include Record Types other than those listed above. The presence of these additional records is reported (including record length) and some conformance testing is performed on common fields for these additional record types. Releases of this tool include a Graphical User Interface (GUI) version and a Command Line Interface (CLI). They are available together with documentation and sample data from the BioCTS web site.

The GUI version allows for interactive conformance testing of transactions. The user can analyze the transaction under test in detail using expandable sections and hierarchical structure views. The tool includes an editor which allows the user to make modifications to the transaction. The CLI version can be called from the command prompt, used within a batch file, or even called from another program to provide automated conformance testing. It can be used as a stand-alone program or incorporated into part of an operational environment, allowing "Passing" transactions to move on while alerting administrators of problem transactions. The CLI version's modes of operation include:

- Interactive: After loading the CLI, the user is prompted for input and output locations (directories/files) and output preferences.

- Single File: The user provides an input file path, an output directory path, and output preferences as parameters and flags on the command line. This will test the single input file.

- Batch File: The user provides an input directory path, an output directory path, and output preferences as parameters and flags on the command line. This will test all files within the input directory. If specified using the appropriate flag, the CLI will test the input directory recursively, testing all sub directories.

\subsection{BioCTS AN-2011 Ongoing Work}

Work continues on the development of CTSs for additional ISO/IEC standards and PIV profiles as well as additional AN-2011 Record Types and encodings. Development of a test tool for AN-2011 NIEM/XML-encoded implementations is underway. Required test assertions not evaluated by the current schema (some Level 1 test assertions and Level 2 assertions) are being implemented ${ }^{3}$. For more information on this planned work, see the tool development roadmaps included in NISTIR $7877[10]$.

The NIST/ITL BioCTS team is developing additional support for multiple environments including a web-based interface (currently in pre-released testing) and a Mono version of the software (Mono is a cross-platform .NET environment available for Linux ${ }^{\circledR}, \operatorname{Mac}{ }^{\circledR}$, and Windows $\left.{ }^{\circledR}\right)$. Additional sample data and utility tools are under development as well. In addition, test assertions for AN-2011 record Type 18, DNA data have been developed and are documented below.

\footnotetext{
${ }^{3}$ Conformance test levels (Level 1, 2, and 3 conformance testing) are defined in NIST's Special Publication 500-295 Section 5.3 (Hierarchy of conformance tests) and are not reproduced in this publication.
} 


\section{Test Assertions for AN-2011 Record Type 18 - DNA Record}

\subsection{AN-2011 Record Type 18 - DNA Record}

The Type-18 record (new to this version of the AN-2011 standard) is required to contain and exchange DNA data. It was developed to provide a basic level of interoperability with the draft format of the ISO/IEC 19794-14 DNA data interchange format developed by ISO/IEC JTC 1/SC 37. The Type-18 record is required to exchange Autosomal Short Tandem Repeat (STR), X-Short Tandem Repeat (X-STR), Y-Short Tandem Repeat (Y-STR), Mitochondrial DNA (mtDNA), Pedigree, and electropherogram images of DNA data. This record type is based upon standardized and commonly used DNA analysis and data reporting conventions. With full consideration to privacy, this standard only uses the non-coding regions of DNA. The regions of the DNA that contain information on a subject's genetic characteristics or traits are deliberately avoided.

\subsection{Record Type 18 Table of Requirement and Assertions}

In preparation for extending BioCTS for AN-2011 to support conformance testing of AN-2011 Record Type 18, the BioCTS team identified over two-hundred test assertions that are necessary to meet the conformance requirements for this Record Type. The test assertions have been organized into a table of requirements and assertions following the format documented in NIST Special Publication 500-295 [8].

Table B.1, which identifies all requirements and associated test assertions for Type 18, uses the test assertion syntax documented Tables 2.1,2.2, and 2.3 found in Section 2.3. The tables define the Operator Definitions, Terms, and Operand Definitions respectively and are also specified in NIST SP 500-295, section 5.5 - Test Assertion Syntax. They have been reproduced in their entirety in this document for consistency, although some entries in the tables may not be used in the test assertions for Record Type 18.

Table B.1 headings are also defined in NIST SP 500-295, Section 5.6 (Tables of requirements and assertions - Table headers) with the exception of Requirement number. Not all test notes included in NIST SP 500-295 apply to the Record Type 18 Table. The three test notes referred to in table B.1 are included below the table. Test Notes 2 and 6 are the same test notes found in NIST SP 500-295, Section 6.3. Test note 18 applies only to Record Type 18. Conformance test levels are defined in NIST's Special Publication 500-295 Section 5.3.

\subsection{Test Assertion Syntax}

Test assertions are expressed according to the operators and operands found in the tables of Operator Definitions and Operand Definitions, except for those instances where the assertion cannot be clearly or easily represented in a mathematical format. In those cases, English is used to express the assertion, and the text is contained within the $<>$ characters.

\subsubsection{Operators}

The table below includes a complete description of the operators used throughout the requirements and assertion tables. 
Table 2.1 - Assertion Syntax: Operator Definitions

\begin{tabular}{|c|c|c|}
\hline \multicolumn{3}{|r|}{ Operator Definitions } \\
\hline Operator & Name & Description \\
\hline AND & Logical And & Tests if both values are true. \\
\hline ELSE & Else & $\begin{array}{l}\text { Combined with the IF operator to specify what expressions are evaluated } \\
\text { when the IF expression is false. }\end{array}$ \\
\hline EQ & Equal To & Tests for equality between two values. \\
\hline GT & Greater Than & Tests if the first value is greater than the second value \\
\hline GTE & $\begin{array}{l}\text { Greater Than or Equal } \\
\text { To }\end{array}$ & Tests if the first value is greater than or equal to the second value. \\
\hline IF & Logical If & Determines if the value or expression is true or false. \\
\hline IFF & IF and Only IF & $\begin{array}{l}\text { Tests the bi-conditional where each of the first and second expressions implies } \\
\text { the other. }\end{array}$ \\
\hline in & $\begin{array}{l}\text { Container } \\
\text { Specification }\end{array}$ & For $\mathrm{X}$ in $\mathrm{Y}$, selects only those $\mathrm{X}$ found in $\mathrm{Y}$. \\
\hline LT & Less Than & Tests if the first value is less than the second value. \\
\hline LTE & $\begin{array}{l}\text { Less Than or Equal } \\
\text { To }\end{array}$ & Tests if the first value is less than or equal to the second value. \\
\hline MO & Member Of & Tests if the value is a contained within the set. \\
\hline MOD & Modulo & For X MOD Y, provides the remainder of X divided by $\mathrm{Y}$. \\
\hline NEQ & Not Equal To & Tests for non-equality between two values. \\
\hline NOT & Negate & Negates any operator or expression that follows. \\
\hline OR & Logical Or & Tests if either value is true \\
\hline $\mathbf{P}: \mathbf{N}$ in $\mathbf{Q}$ & Query & Selects the Nth occurrence of $\mathrm{P}$ in $\mathrm{Q}$. \\
\hline ST & Such That & Enforces a condition upon the specified value or expression. \\
\hline THEN & Then & $\begin{array}{l}\text { Combined with the IF operator to specify what expressions are evaluated } \\
\text { when the IF expression is true. }\end{array}$ \\
\hline to & Range Selection & For X to Y, selects a set of values Z ST Z GTE X AND LTE Y \\
\hline \# & All & Provides all valid values. \\
\hline : & $\begin{array}{l}\text { Data Element } \\
\text { Selection }\end{array}$ & For X:N, selects the Nth element in X. \\
\hline , & Range Concatenation & For $\mathrm{X}, \mathrm{Y}$, represents the set of values containing both $\mathrm{X}$ and $\mathrm{Y}$. \\
\hline . & Field Selection & For X.Y, selects the field specified by Y in Record X. \\
\hline$\langle>$ & English Expression & Contains English text that could not be reasonably expressed mathematically. \\
\hline\{\} & Value & For $\{\mathrm{X}\}$, provides the value of $\mathrm{X}$ \\
\hline [ ] & Set & The set to be tested. \\
\hline
\end{tabular}

\subsubsection{Terms}

The table below provides a complete description of the terms used throughout the requirements and assertion tables.

Table 2.2 - Assertion Syntax: Terms

\begin{tabular}{|c|l|l|}
\hline \multicolumn{2}{|c|}{ Term Definitions } \\
\hline Term & Name & Description \\
\hline Field(s) & Field & Field structure as defined by the AN 1-2011 standard. \\
\hline InfoItem & $\begin{array}{l}\text { US Separated } \\
\text { Information Item }\end{array}$ & $\begin{array}{l}\text { Information Item separated by the ASCII US (0x1F) separator } \\
\text { character }\end{array}$ \\
\hline
\end{tabular}




\begin{tabular}{|c|l|l|}
\hline Integers & Integer Set & Set of all integers. \\
\hline NA & Not Applicable & The test or condition is not applicable. \\
\hline Unsupported & Unsupported & $\begin{array}{l}\text { The requirement is not supported in this version of the CTM. This } \\
\text { may be the result of the related conformance test requiring } \\
\text { additional research, or the result of the test being infeasible (level } 3 \\
\text { only). }\end{array}$ \\
\hline Record(s) & Record & Record structure as defined by the AN 1-2011 standard. \\
\hline Subfield & RS Separated Subfield & Subfield separated by the ASCII RS (0x1E) separator character \\
\hline Transaction & Transaction & Transaction structure as defined by the AN 1-2011 standard. \\
\hline TRUE & True & $\begin{array}{l}\text { The test always evaluates to true because there is no defined value for } \\
\text { testing, or there is no value for which the test will fail. }\end{array}$ \\
\hline
\end{tabular}

\subsubsection{Operands}

The table below includes a complete description of the operands used throughout the requirements and assertion tables. The parameter $\mathrm{X}$ may represent any combination of operands, terms, and operators.

Table 2.3 - Assertion Syntax: Operand Definitions

\begin{tabular}{|c|c|c|}
\hline \multicolumn{3}{|c|}{ Operand Definitions } \\
\hline Operand & Name & Description \\
\hline All $(\mathbf{X})$ & All Occurrences & Returns all occurrences of X. \\
\hline $\operatorname{ASCII}(\mathbf{X})$ & ASCII Values & $\begin{array}{l}\text { Specifies that all values represented by } \mathrm{X} \text { are ASCII } \\
\text { values. Ex. ASCII(a) is } 0 \times 61\end{array}$ \\
\hline $\operatorname{Bytes}(\mathbf{X})$ & Byte Data & Returns the set of bytes contained in X. \\
\hline Count $(\mathbf{X})$ & Count Occurrences & Returns the number of occurrences of X. \\
\hline $\operatorname{DataLength}(\mathbf{X})$ & $\begin{array}{l}\text { Length Of (without Special } \\
\text { Characters) }\end{array}$ & $\begin{array}{l}\text { Returns the length of } \mathrm{X} \text { without counting the characters } \\
\text { ASCII( US, RS, FS). }\end{array}$ \\
\hline FieldNumber(X) & Field Number & Returns the field number of $X$ \\
\hline $\operatorname{First}(\mathbf{X})$ & First Occurrence & Returns the first occurrence of X. \\
\hline $\begin{array}{c}\text { For(X EQ A to B) } \\
\{\text { Expression(s) }\}\end{array}$ & For Loop & $\begin{array}{l}\text { Evaluates each Expression for the range specified by A to } \\
\text { B. }\end{array}$ \\
\hline $\begin{array}{c}\text { ForEach }(\mathbf{X}) \\
\{\operatorname{Expression}(\mathbf{s})\}\end{array}$ & For Each & $\begin{array}{l}\text { Evaluates each Expression for every occurrence of X } \\
\text { found. }\end{array}$ \\
\hline Last $(\mathbf{X})$ & Last Occurrence & Returns the last occurrence of X. \\
\hline Length $(X)$ & Length Of & Returns the length of X. \\
\hline $\operatorname{Max}(\mathbf{X})$ & Maximum Value & Returns the maximum value in the set $\mathrm{X}$. \\
\hline $\operatorname{Min}(\mathbf{X})$ & Minimum Value & Returns the minimum value in the set $\mathrm{X}$. \\
\hline $\operatorname{Next}(X)$ & Next Occurrence & $\begin{array}{l}\text { Returns the next occurrence of X. Only for use within } \\
\text { ForEach Operand's Expression(s). }\end{array}$ \\
\hline Pair(A,B) of X & Pair & $\begin{array}{l}\text { Returns all pairs of X. Only for use as a parameter in a } \\
\text { ForEach Operand. }\end{array}$ \\
\hline ParentField(X) & Parent Field & Returns the Field that contains X. \\
\hline ParentRecord(X) & Parent Record & Returns the Record that contains X. \\
\hline $\operatorname{Present}(\mathbf{X})$ & Value Present & $\begin{array}{l}\text { Returns TRUE if X is present, FALSE otherwise. For } \\
\text { subfields in Traditional Encoding, the US and RS } \\
\text { separators are always present. Therefore the Present(X) } \\
\text { operand returns TRUE if the value between the separators }\end{array}$ \\
\hline
\end{tabular}




\begin{tabular}{|c|l|l|}
\hline Previous(X) & Previous Occurrence & $\begin{array}{l}\text { Returns the previous occurrence of X. Only for use within } \\
\text { ForEach Operand's Expression(s). }\end{array}$ \\
\hline Second(X) & Second Occurrence & Returns the second occurrence of X. \\
\hline Type(X) & Record Type & Returns the Record Type of X. \\
\hline $\begin{array}{c}\text { Var(X) }\{\text { Selection } \\
\text { Statement }\}\end{array}$ & Variable & $\begin{array}{l}\text { Assigns the entity specified by the Selection Statement to } \\
\text { the name X. The assignment is valid for the remainder of } \\
\text { the assertion text. }\end{array}$ \\
\hline $\mathbf{X E I m}(\mathbf{X})$ & XML Element & Returns the XML Element with name X. \\
\hline
\end{tabular}

\subsection{Table of Requirements and Assertions - Table headers}

The following describe the headings of the tables of requirements and assertions found in Annex B:

- Requirement \# and ID: Defines a unique requirement number and a unique identifier for the requirement and associated assertion or set of assertions. For Record Type requirements, the Requirement \# is in the form RTN.M, where $\mathrm{N}$ is the Record Type and $\mathrm{M}$ is the sequential number of the requirement. If additional requirements must be entered in the future, the new requirement number will be specified using an additional number, as in RTN.M.A, where A is the additional number. The Requirement ID provides reference to the type of requirement (e.g., transaction, record, and field), and is in the form of "Type: Description" where type may be "Transaction", "Record", or "Field". For requirements found in Annex B of the AN2011 standard, the Requirement ID is preceded by "Traditional-".

- Ref. in Base Std. (Reference in Base Standard): Identifies the clause (or section) where the requirement is included in the $\mathrm{AN}-2011$ standard. In some cases the reference includes additional information such as a Table number.

- Requirement Summary: Provides a summary of the requirement detailed as textual information or an interpretation of the requirement in the standard. It provides the essentials of the requirement but may not provide all the text necessary to understand it. The $<>$ operator is used in the Requirement Summary column of the tables to represent text not found in the standard, but that may help indicate what requirement is being represented.

- Level: Indicates whether Level 1 or Level 2 conformance testing is required to address the assertion identified in the Assertion ID column of the same row. Level 3 conformance tests are indicated only when necessary to show that the requirement is not currently testable or addressed.

- Status: Reflects the status specified in the AN-2011 standard:
○ M: Mandatory
○ O: Optional
○ D: Dependent
○ M : Mandatory within the optional field/subfield
○ O介: Optional within the optional field/subfield 
○ -: Varying statuses. The assertion addresses many fields or subfields of multiple statuses.

- Assertion ID: Defines an identifier of a specific test assertion within the set of test assertions associated with a requirement.

- Test Assertion: Provides, whenever possible, a mathematical equation or a procedure using the language specified by the operators, operands, and terms.

○ The $<>$ operator is used to contain plain text whenever a mathematical formula or simple procedure cannot be detailed.

- Test Note: Contains the ID of the test note. Test notes provide additional information related to the assertion and are included below the tables.

- Imp. Support (Implementation Support): Denotes a supplier's implementation support of a particular requirement ("Y"/"N"). A note can follow the table when providing more details of implementation support (or the lack of it) is required.

- Supported Range: Indicates a range of values supported, especially when it is different than the full range of values specified in the standard. When an information item is specified as a single value, or does not address a range of values, a N/A should be used.

- Test Result: This column is used to denote the test results. For file and record-level results the results are either "Pass" or "Fail". The field-level results should be indicated as "Ok", "Error", "Warning" and "Note". Explanatory notes can be added below the table.

- Applicable to (T, X, B, B* or $\mathbf{X}^{*}$ ) - (Applicability): This table header indicates which assertions differ (in values required or conditions) between Traditional and NIEM encoding. This table header does not indicate which assertions are addressed by the XML Schema and which will need to be addressed in code. Valid values are:

○ T: The assertion only applies to the Traditional encoding as described in Annex B of AN-2011.

O X: The assertion only applies to the NIEM-conformant (XML) encoding as described in Annex C of AN-2011.

○ B: The assertion is applicable to both Traditional and NIEM (XML) encoding.

- Following the conventions in the AN-2011 standard, test Assertions are expressed using constructs (fields, records, etc.) found in Traditional encoding (such as xx.002 for the second field of each record type). The same assertion applies for the XML elements that correspond to the Traditional constructs. For example, 10.006 in Traditional Encoding corresponds to XML Element $<$ biom:ImageHorizontalLineLengthPixelQuantity $>$.

- Some assertions reference subfields, however, NIEM encoding uses nested elements. Expression of Test Assertions that include subfields in the XML encoding requires further review. These assertions are listed with the following applicability values:

- $\mathrm{X}^{*}$ indicates that the assertion applies only to NIEM-conformant (XML) encoding. 
- $\mathrm{B}^{*}$ indicates that the assertion is applicable to both Traditional and NIEM (XML) encodings. 
Annex A - References

[1] BioAPI Conformance Test Suite and associated documentation download: http://www.nist.gov/itl/csd/biometrics/bioapicts.cfm (accessed 02/25/2013).

[2] Conformance Test Architecture for Biometric Information Records and CBEFF Patron Format A Conformance Test Suite: http://www.nist.gov/it//csd/biometrics/biocbeffcts.cfm (accessed 02/25/2013).

[3] CTA and CTSs for Biometric Data Interchange Format Standards Developed by INCITS M1, http://www.nist.gov/itl/csd/biometrics/incitsm1.cfm (accessed 02/25/2013).

[4] Conformance Test Architecture and Test Suite for ANSI/NIST-ITL 1-2007, http://www.nist.gov/itl/csd/biometrics/ansi-nist-legacy.cfm (accessed 02/25/2013).

[5] NIST/ITL CSD BioCTS web site: http://www.nist.gov/itt/csd/biometrics/biocta_download.cfm (accessed 02/25/2013).

[6] NIST Special Publication 500-290, American National Standard for Information Systems Data Format for the Interchange of Fingerprint, Facial \& Other Biometric Information, B. Wing (Editor), November 2011: http://www.nist.gov/customcf/get_pdf.cfm?pub_id=910136 (accessed 02/25/2013).

[7] NISTIR 7806, ANSI/NIST-ITL 1-2011 Requirements and Conformance Test Assertions, C. J. McGinnis, D. Yaga and F. L. Podio, September 2011.

[8] NIST Special Publication 500-295, Conformance Testing Methodology for ANSI/NIST-ITL 1-2011, Data Format for the Interchange of Fingerprint, Facial \& Other Biometric Information (Release 1.0), Editors: F. L. Podio, D. Yaga, C. J. McGinnis, August 2012.

[9] BioCTS for AN2011 web page: http://www.nist.gov/itt/csd/biometrics/ansi-nist.cfm (accessed 02/25/2013).

[10] NISTIR 7877, BioCTS 2012: Advanced Conformance Test Architectures and Test Suites for Biometric Data Interchange Formats and Biometric Information Records, F. L. Podio, D. Yaga and C. J. McGinnis, September 2012: http://nvlpubs.nist.gov/nistpubs/ir/2012/NIST.IR.7877.pdf (accessed 02/25/2013). 


\section{Appendix B - Record Type-18: DNA Record Requirements and Assertions}

\section{B.1 Record Type 18 - DNA Record Requirements and Test Assertions}

Table B.1 - Assertions for Record Type 18 - DNA Record

\begin{tabular}{|c|c|c|c|c|c|c|c|c|c|c|c|}
\hline Req. \# - ID & $\begin{array}{l}\text { Ref. in } \\
\text { Base } \\
\text { Std. }\end{array}$ & $\begin{array}{l}\text { Requirement } \\
\text { Summary }\end{array}$ & $\begin{array}{l}\text { L } \\
\text { e } \\
\text { v } \\
\text { e } \\
\text { I }\end{array}$ & \begin{tabular}{l|l}
$s$ \\
$t$ \\
$a$ \\
$t$ \\
$u$ \\
$s$
\end{tabular} & $\frac{\text { Assertion }}{\text { ID }}$ & $\begin{array}{c}\text { Test } \\
\text { Assertion }\end{array}$ & $\frac{\text { Test }}{\text { Note }}$ & $\begin{array}{l}\text { Imp. } \\
\text { Support }\end{array}$ & $\begin{array}{l}\text { Supported } \\
\text { Range }\end{array}$ & $\frac{\text { Test }}{\text { Result }}$ & $\begin{array}{l}\text { Applicable } \\
\text { to }(T, X, B \text {, } \\
\left.B^{*}, \text { or } X^{*}\right)\end{array}$ \\
\hline \multicolumn{12}{|c|}{ 8.18: Record Type-18: DNA record } \\
\hline \multirow[t]{5}{*}{$\begin{array}{l}\text { RT18.1 - } \\
\text { Field: } \\
\text { Type18- } \\
\text { Subfield } \\
\text { Occurrence }\end{array}$} & \multirow[t]{5}{*}{ Table 79} & \multirow[t]{5}{*}{$\begin{array}{l}<\text { Table } 79 \text { specifies which fields contain } \\
\text { subfields as well as the number of } \\
\text { occurrences permitted.> }\end{array}$} & 1 & M & $\begin{array}{l}\text { NIEM- } \\
\text { Type18- } \\
\text { Cardinality- } \\
\text { SubElemen } \\
\text { ts }\end{array}$ & $\begin{array}{l}<\text { The Type- } 18 \text { table in Annex } \mathrm{G} \text { of the base } \\
\text { standard specifies the type and number of sub } \\
\text { elements required for each field.> }\end{array}$ & & & & & $\mathrm{x}$ \\
\hline & & & 1 & M & $\begin{array}{c}18 .[001 \text { to } \\
010,012 \text { to } \\
015,017 \\
020,022 \\
993,998]- \\
\text { SubfieldCo } \\
\text { unt }\end{array}$ & $\begin{array}{l}\text { Count(Subfields in } 18 .[001 \text { to } 010,012 \text { to } 015 \text {, } \\
017,020,022,993,998] \text { EQ } 1\end{array}$ & & & & & $\mathrm{~T}$ \\
\hline & & & 1 & M & $\begin{array}{c}\text { 18.[001, } \\
002,004, \\
005,007, \\
008,012 \text { to } \\
014,020 \\
022,993]- \\
\text { InfoltemCo } \\
\text { unt }\end{array}$ & $\begin{array}{l}\text { Count(Infoltems in Subfield:1 in 18.[ 001, 002, } \\
004,005,007,008,012 \text { to 014, 020, 022, 993]) } \\
\text { EQ } 1\end{array}$ & & & & & T \\
\hline & & & 1 & $M$ & $\begin{array}{l}\text { 18.003- } \\
\text { InfoltemCo } \\
\quad \text { unt }\end{array}$ & Count(Infoltems in 18.003) MO [1 to 7] & & & & & $\mathrm{T}$ \\
\hline & & & 1 & M & $\begin{array}{l}\text { 18.006- } \\
\text { InfoltemCo }\end{array}$ & Count(Infoltems in 18.006) MO [1 to 8] & & & & & $\mathrm{T}$ \\
\hline
\end{tabular}




\begin{tabular}{|c|c|c|c|c|c|c|c|c|c|c|c|}
\hline Req. \# - ID & $\begin{array}{l}\text { Ref. in } \\
\text { Base } \\
\text { Std. }\end{array}$ & $\begin{array}{l}\text { Requirement } \\
\text { Summary }\end{array}$ & $\begin{array}{l}\mathrm{L} \\
\mathrm{e} \\
\mathrm{v} \\
\mathrm{e} \\
\mathrm{l}\end{array}$ & $\begin{array}{l}\mathrm{s} \\
\mathrm{t} \\
\mathrm{a} \\
\mathrm{t} \\
\mathrm{u} \\
\mathrm{s}\end{array}$ & $\begin{array}{l}\text { Assertion } \\
\text { ID }\end{array}$ & $\begin{array}{c}\text { Test } \\
\text { Assertion }\end{array}$ & $\begin{array}{l}\text { Test } \\
\text { Note }\end{array}$ & $\begin{array}{c}\text { Imp. } \\
\text { Support }\end{array}$ & $\begin{array}{l}\text { Supported } \\
\text { Range }\end{array}$ & $\begin{array}{c}\text { Test } \\
\text { Result }\end{array}$ & $\begin{array}{l}\text { Applicable } \\
\text { to }(T, X, B \text {, } \\
\left.B^{*} \text {, or } X^{*}\right)\end{array}$ \\
\hline \multicolumn{12}{|c|}{ 8.18: Record Type-18: DNA record } \\
\hline & & & & & unt & & & & & & \\
\hline & & & 1 & $\mathrm{O}$ & $\begin{array}{l}\text { 18.009- } \\
\text { InfoltemCo } \\
\text { unt }\end{array}$ & Count(Infoltems in 18.009) MO [4 to 7] & & & & & $\mathrm{T}$ \\
\hline & & & 1 & M & $\begin{array}{l}\text { 18.010- } \\
\text { InfoltemCo } \\
\text { unt }\end{array}$ & Count(Infoltems in 18.010) MO [1, 2] & & & & & $\mathrm{T}$ \\
\hline & & & 1 & M & $\begin{array}{l}\text { 18.011- } \\
\text { InfoltemCo } \\
\text { unt }\end{array}$ & $\begin{array}{l}\text { Foreach(Subfield in 18.011) } \\
\{ \\
\text { Count(Infoltems in Subfield) EQ } 1 \\
\}\end{array}$ & & & & & $\mathrm{T}$ \\
\hline & & & 1 & M & $\begin{array}{l}\text { 18.015- } \\
\text { InfoltemCo } \\
\text { unt }\end{array}$ & Count(Infoltems in 18.015) MO [2 to 5] & & & & & $\mathrm{T}$ \\
\hline & & & 1 & $\mathrm{D}$ & $\begin{array}{l}\text { 18.016- } \\
\text { SubfieldCo } \\
\text { unt }\end{array}$ & Count(Subfields in 18.016) GTE 1 & & & & & $\mathrm{~T}$ \\
\hline & & & 1 & $\mathrm{D}$ & $\begin{array}{l}\text { 18.016- } \\
\text { InfoltemCo } \\
\text { unt }\end{array}$ & $\begin{array}{l}\text { ForEach(Subfield in 18.016) } \\
\{ \\
\text { Count(Infoltems in Subfield) MO [6 to 15] } \\
\}\end{array}$ & & & & & $\mathrm{T}$ \\
\hline & & & 1 & $\mathrm{D}$ & $\begin{array}{l}\text { 18.017- } \\
\text { InfoltemCo } \\
\text { unt }\end{array}$ & Count(Infoltems in 18.017) EQ 8 & & & & & $\mathrm{~T}$ \\
\hline & & & 1 & $\mathrm{D}$ & $\begin{array}{l}18.018- \\
\text { SubfieldCo } \\
\text { unt }\end{array}$ & Count(Subfields in 18.018) GTE 1 & & & & & $\mathrm{~T}$ \\
\hline & & & 1 & D & $\begin{array}{l}\text { 18.018- } \\
\text { InfoltemCo } \\
\text { unt }\end{array}$ & $\begin{array}{l}\text { Foreach(Subfield in 18.018) } \\
\{ \\
\text { Count(Infoltems in Subfield) GTE } 1 \\
\}\end{array}$ & & & & & $\mathrm{T}$ \\
\hline & & & 1 & $\mathrm{D}$ & $\begin{array}{l}\text { 18.019- } \\
\text { SubfieldCo } \\
\text { unt }\end{array}$ & Count(Subfields in 18.019) GTE 1 & & & & & $\mathrm{~T}$ \\
\hline & & & 1 & $\mathrm{D}$ & 18.019- & Foreach(Subfield in 18.019) & & & & & $\mathrm{T}$ \\
\hline
\end{tabular}




\begin{tabular}{|c|c|c|c|c|c|c|c|c|c|c|c|}
\hline Req. \# - ID & $\begin{array}{l}\text { Ref. in } \\
\text { Base } \\
\text { Std. }\end{array}$ & $\begin{array}{l}\text { Requirement } \\
\text { Summary }\end{array}$ & $\begin{array}{l}\mathrm{L} \\
\mathrm{e} \\
\mathrm{v} \\
\mathrm{e} \\
\mathrm{I}\end{array}$ & $\begin{array}{l}\mathrm{s} \\
\mathrm{t} \\
\mathrm{a} \\
\mathrm{t} \\
\mathrm{u} \\
\mathrm{s}\end{array}$ & $\begin{array}{l}\text { Assertion } \\
\text { ID }\end{array}$ & $\begin{array}{c}\text { Test } \\
\text { Assertion }\end{array}$ & $\begin{array}{l}\text { Test } \\
\text { Note }\end{array}$ & $\begin{array}{l}\text { Imp. } \\
\text { Support }\end{array}$ & $\begin{array}{l}\text { Supported } \\
\text { Range }\end{array}$ & $\begin{array}{c}\text { Test } \\
\text { Result }\end{array}$ & $\begin{array}{l}\text { Applicable } \\
\text { to }(T, X, B \text {, } \\
\left.B^{*} \text {, or } X^{*}\right)\end{array}$ \\
\hline \multicolumn{12}{|c|}{ 8.18: Record Type-18: DNA record } \\
\hline & & & & & $\begin{array}{l}\text { InfoltemCo } \\
\text { unt }\end{array}$ & $\begin{array}{l}\{ \\
\text { Count(Infoltems in Subfield) MO [4 to 5] }\end{array}$ & & & & & \\
\hline & & & 1 & D & $\begin{array}{l}18.021- \\
\text { SubfieldCo } \\
\text { unt }\end{array}$ & Count(Subfields in 18.021) GTE 1 & & & & & $\mathrm{~T}$ \\
\hline & & & 1 & $\mathrm{D}$ & $\begin{array}{l}\text { 18.021- } \\
\text { InfoltemCo } \\
\text { unt }\end{array}$ & $\begin{array}{l}\text { Foreach(Subfield in 18.021) } \\
\{ \\
\text { Count(Infoltems in Subfield) EQ } 3 \\
\}\end{array}$ & & & & & $\mathrm{T}$ \\
\hline & & & 1 & D & $\begin{array}{l}\text { 18.023- } \\
\text { SubfieldCo } \\
\text { unt }\end{array}$ & Count(Subfields in 18.023) GTE 1 & & & & & $\mathrm{~T}$ \\
\hline & & & 1 & $\mathrm{D}$ & $\begin{array}{l}\text { 18.023- } \\
\text { InfoltemCo } \\
\text { unt }\end{array}$ & $\begin{array}{l}\text { Foreach(Subfield in 18.023) } \\
\{ \\
\text { Count(Infoltems in Subfield) MO [4 to 5] } \\
\}\end{array}$ & & & & & $\mathrm{T}$ \\
\hline & & & 1 & 0 & $\begin{array}{l}18.902- \\
\text { SubfieldCo } \\
\text { unt }\end{array}$ & Count(Subfields in 18.902) GTE 1 & & & & & $\mathrm{~T}$ \\
\hline & & & 1 & 0 & $\begin{array}{l}\text { 18.902- } \\
\text { InfoltemCo } \\
\text { unt }\end{array}$ & $\begin{array}{l}\text { ForEach(Subfield in 18.902) } \\
\{ \\
\text { Count(Infoltems in Subfield) EQ } 4 \\
\}\end{array}$ & & & & & $\mathrm{T}$ \\
\hline & & & 1 & 0 & $\begin{array}{l}18.995- \\
\text { SubfieldCo } \\
\text { unt }\end{array}$ & Count(Subfields in 17.995) MO [1 to 255] & & & & & $\mathrm{T}$ \\
\hline & & & 1 & 0 & $\begin{array}{l}\text { 18.995- } \\
\text { InfoltemCo } \\
\text { unt }\end{array}$ & $\begin{array}{l}\text { ForEach(Subfield in 17.995) } \\
\{ \\
\text { Count(Infoltems in Subfield) MO [1,2] } \\
\}\end{array}$ & & & & & $\mathrm{T}$ \\
\hline & & & - & 0 & $\begin{array}{l}\text { 18.998- } \\
\text { Subfields }\end{array}$ & <See Requirement ID: "Field: Geographic"> & $\mathrm{t}-2$ & & & & \\
\hline $\begin{array}{l}\text { RT18.2 - } \\
\text { Field: }\end{array}$ & Table 79 & $\begin{array}{l}<\text { Table } 79 \text { specifies the Condition Code for } \\
\text { each field. }>\end{array}$ & 1 & - & $\begin{array}{l}\text { [18.001 to } \\
18.006\end{array}$ & $\begin{array}{l}\text { Present(18.001 to } 18.006,18.010,18.011 \\
18.013 \text { to } 18.015)\end{array}$ & & & & & B \\
\hline
\end{tabular}




\begin{tabular}{|c|c|c|c|c|c|c|c|c|c|c|c|}
\hline Req. \# - ID & $\begin{array}{l}\text { Ref. in } \\
\text { Base } \\
\text { Std. }\end{array}$ & $\begin{array}{l}\text { Requirement } \\
\text { Summary }\end{array}$ & $\begin{array}{l}\text { L } \\
\text { e } \\
\text { v } \\
\text { e } \\
\text { I }\end{array}$ & \begin{tabular}{l|l|} 
& \\
$t$ \\
$a$ \\
$t$ \\
$u$ \\
$s$
\end{tabular} & $\begin{array}{l}\text { Assertion } \\
\text { ID }\end{array}$ & $\begin{array}{c}\text { Test } \\
\text { Assertion }\end{array}$ & $\begin{array}{l}\text { Test } \\
\text { Note }\end{array}$ & $\begin{array}{l}\text { Imp. } \\
\text { Support }\end{array}$ & $\begin{array}{l}\text { Supported } \\
\text { Range }\end{array}$ & $\begin{array}{l}\text { Test } \\
\text { Result }\end{array}$ & $\begin{array}{l}\text { Applicable } \\
\text { to }(T, X, B \text {, } \\
\left.B^{*}, \text { or } X^{*}\right)\end{array}$ \\
\hline \multicolumn{12}{|c|}{ 8.18: Record Type-18: DNA record } \\
\hline \multirow[t]{2}{*}{$\begin{array}{l}\text { Type18- } \\
\text { CondCode }\end{array}$} & & & & & $\begin{array}{c}\text { 18.010, } \\
18.011, \\
18.013 \text { to } \\
18.015]- \\
\text { Mandatory } \\
\text { CondCode }\end{array}$ & & & & & & \\
\hline & & & 1 & - & $\begin{array}{c}\text { [18.024 to } \\
18.199, \\
18.901 \\
18.903 \text { to } \\
18.992 \\
18.994, \\
18.996, \\
18.997 \\
18.999]- \\
\text { Reserved }\end{array}$ & $\begin{array}{l}\text { NOT Present( } 18.024 \text { to } 18.199,18.901,18.903 \\
\text { to } 18.992,18.994,18.996,18.997,18.999)\end{array}$ & & & & & B \\
\hline $\begin{array}{l}\text { RT18.3 - } \\
\text { Record: } \\
18.007 \\
\text { Dependent }\end{array}$ & $\begin{array}{l}\text { Table 79, } \\
8.18 .7\end{array}$ & $\begin{array}{l}\text { This field is mandatory if the value of DSD } \\
\text { is equal to } 1 .\end{array}$ & 2 & $\mathrm{D}$ & $\begin{array}{l}\text { 18.007- } \\
\text { CondCode } \\
\text { Dependent }\end{array}$ & $\begin{array}{l}\text { IF }\{\text { Infoltem: } 1 \text { in } 18.005\} \text { EQ } 1 \\
\text { THEN Present(18.007) }\end{array}$ & & & & & B \\
\hline $\begin{array}{l}\text { RT18.4 - } \\
\text { Record: } \\
18.008 \\
\text { Dependent }\end{array}$ & $\begin{array}{l}\text { Table } 79, \\
8.18 .8\end{array}$ & $\begin{array}{l}\text { This field is optional and ... is only filled in } \\
\text { if } D S D=1 .\end{array}$ & 2 & $\mathrm{D}$ & $\begin{array}{l}\text { 18.008- } \\
\text { CondCode } \\
\text { Dependent }\end{array}$ & $\begin{array}{l}\text { IF Present(18.008), } \\
\text { THEN \{Infoltem:1 in } 18.005\} \text { EQ } 1\end{array}$ & & & & & B \\
\hline $\begin{array}{l}\text { RT18.5 - } \\
\text { Record: } \\
18.016 \\
\text { Dependent }\end{array}$ & $\begin{array}{c}\text { Table } 79, \\
8.18 .16\end{array}$ & $\begin{array}{l}\text { This optional field } \ldots \text { is only present if } \\
\text { Field } 18.011 \text { : Sample typing information / } \\
\text { STI has a subfield with the value } 0 .\end{array}$ & 2 & $\mathrm{D}$ & $\begin{array}{l}\text { 18.016- } \\
\text { CondCode } \\
\text { Dependent }\end{array}$ & $\begin{array}{l}\text { IF Present(18.016), } \\
\text { THEN Present(Subfield in } 18.011 \text { ST \{Infoltem:1 } \\
\text { in Subfield\} EQ 0) }\end{array}$ & & & & & B \\
\hline $\begin{array}{l}\text { RT18.6 - } \\
\text { Record: } \\
18.017 \\
\text { Dependent }\end{array}$ & $\begin{array}{l}\text { Table 79, } \\
8.18 .17\end{array}$ & $\begin{array}{l}\text { This is an optional field...This field is only } \\
\text { present if Field 18.011: Sample typing } \\
\text { information / STI has a subfield with the } \\
\text { value } 1 .\end{array}$ & 2 & $\mathrm{D}$ & $\begin{array}{l}\text { 18.017- } \\
\text { CondCode } \\
\text { Dependent }\end{array}$ & $\begin{array}{l}\text { IF Present(18.017), } \\
\text { THEN Present(Subfield in } 18.011 \text { ST \{lnfoltem:1 } \\
\text { in Subfield\} EQ 1) }\end{array}$ & & & & & B \\
\hline $\begin{array}{l}\text { RT18.7 - } \\
\text { Record: } \\
18.018\end{array}$ & $\begin{array}{l}\text { Table 79, } \\
8.18 .18\end{array}$ & $\begin{array}{l}\text { This optional field } \ldots \text { is only present if } \\
\text { Field } 18.011 \text { : Sample typing information / } \\
\text { STI has a subfield with the value } 4 \text {. }\end{array}$ & 2 & $\mathrm{D}$ & $\begin{array}{l}\text { 18.018- } \\
\text { CondCode } \\
\text { Dependent }\end{array}$ & $\begin{array}{l}\text { IF Present(18.018), } \\
\text { THEN Present(Subfield in } 18.011 \text { ST \{Infoltem:1 } \\
\text { in Subfield\} EQ 4) }\end{array}$ & & & & & B \\
\hline
\end{tabular}




\begin{tabular}{|c|c|c|c|c|c|c|c|c|c|c|c|}
\hline Req. \# - ID & $\begin{array}{l}\text { Ref. in } \\
\text { Base } \\
\text { Std. }\end{array}$ & $\begin{array}{l}\text { Requirement } \\
\text { Summary }\end{array}$ & $\begin{array}{l}\text { L } \\
\text { e } \\
\text { v } \\
\text { e } \\
\text { I }\end{array}$ & $\begin{array}{l}\mathrm{S} \\
\mathrm{t} \\
\mathrm{a} \\
\mathrm{t} \\
\mathrm{u} \\
\mathrm{s}\end{array}$ & $\begin{array}{l}\text { Assertion } \\
\text { ID }\end{array}$ & $\begin{array}{c}\text { Test } \\
\text { Assertion }\end{array}$ & $\begin{array}{l}\text { Test } \\
\text { Note }\end{array}$ & $\begin{array}{l}\text { Imp. } \\
\text { Support }\end{array}$ & $\begin{array}{l}\text { Supported } \\
\text { Range }\end{array}$ & $\begin{array}{c}\text { Test } \\
\text { Result }\end{array}$ & $\begin{array}{l}\text { Applicable } \\
\text { to }(T, X, B \text {, } \\
\left.B^{*}, \text { or } X^{*}\right)\end{array}$ \\
\hline \multicolumn{12}{|c|}{ 8.18: Record Type-18: DNA record } \\
\hline \multicolumn{12}{|l|}{ Dependent } \\
\hline $\begin{array}{l}\text { RT18.8 - } \\
\text { Record: } \\
18.019 \\
\text { Dependent }\end{array}$ & $\begin{array}{l}\text { Table 79, } \\
8.18 .19\end{array}$ & $\begin{array}{l}\text { This optional field ... is only present if } \\
\text { Field } 18.011 \text { : Sample typing information / } \\
\text { STI has a subfield with the value } 2 \text {. }\end{array}$ & 2 & $\mathrm{D}$ & $\begin{array}{l}\text { 18.019- } \\
\text { CondCode } \\
\text { Dependent }\end{array}$ & $\begin{array}{l}\text { IF Present(18.019), } \\
\text { THEN Present(Subfield in } 18.011 \text { ST \{Infoltem: } 1 \\
\text { in Subfield\} EQ 2) }\end{array}$ & & & & & B \\
\hline $\begin{array}{l}\text { RT18.9 - } \\
\text { Record: } \\
18.021 \\
\text { Dependent }\end{array}$ & $\begin{array}{l}\text { Table 79, } \\
8.18 .21\end{array}$ & $\begin{array}{l}\text { This field is only present if Field } 18.020 \text { : } \\
\text { DNA genotype distribution / DGD has a } \\
\text { Value. }\end{array}$ & 2 & $\mathrm{D}$ & $\begin{array}{l}\text { 18.021- } \\
\text { CondCode } \\
\text { Dependent }\end{array}$ & $\begin{array}{l}\text { IF Present(18.021) } \\
\text { THEN Present(18.020\} AND DataLength(18.020) } \\
\text { GT } 0\end{array}$ & & & & & B \\
\hline $\begin{array}{l}\text { RT18.10 - } \\
\text { Record: } \\
18.023 \\
\text { Dependent }\end{array}$ & $\begin{array}{l}\text { Table 79, } \\
8.18 .23\end{array}$ & $\begin{array}{l}\text { This optional field ... is only present if } \\
\text { Field 18.011: Sample typing information / } \\
\text { STI has a subfield with the value } 3 \text {. }\end{array}$ & 2 & $\mathrm{D}$ & $\begin{array}{l}\text { 18.023- } \\
\text { CondCode } \\
\text { Dependent }\end{array}$ & $\begin{array}{l}\text { IF Present(18.023), } \\
\text { THEN Present(Subfield in } 18.011 \text { ST \{Infoltem:1 } \\
\text { in Subfield\} EQ 3) }\end{array}$ & & & & & B \\
\hline \multirow[t]{8}{*}{$\begin{array}{l}\text { RT18.11 - } \\
\text { Field: } \\
\text { Type18- } \\
\text { CharType }\end{array}$} & \multirow[t]{8}{*}{$\begin{array}{l}8.18 \\
\text { Table } 79\end{array}$} & \multirow[t]{8}{*}{$\begin{array}{l}<\text { Table } 79 \text { specifies the Character Type for } \\
\text { each field that contains no subfields.> }\end{array}$} & 1 & - & $\begin{array}{c}\text { 18.[001, } \\
002,005, \\
007,008, \\
\text { 020]- } \\
\text { CharType }\end{array}$ & $\begin{array}{l}\text { Bytes }(18 .[001,002,005,007,008,020]) \mathrm{MO} \\
\text { [0x30 to } 0 \times 39]\end{array}$ & & & & & B \\
\hline & & & 1 & - & $\begin{array}{l}\text { 18.[012, } \\
\text { 022]- } \\
\text { CharType }\end{array}$ & TRUE & & & & & B \\
\hline & & & 1 & M & $\begin{array}{l}\text { 18.004- } \\
\text { CharType }\end{array}$ & <See Requirement ID: "Field: Source Agency".> & $\mathrm{t}-2$ & & & & \\
\hline & & & 1 & M & $\begin{array}{l}\text { 18.013- } \\
\text { CharType }\end{array}$ & Bytes(18.013) MO [0x30 to $0 \times 39]$ & & & & & T \\
\hline & & & 1 & M & $\begin{array}{l}\text { NIEM- } \\
\text { 18.013- } \\
\text { CharType }\end{array}$ & Bytes(18.013) MO [0x30 to $0 \times 39,0 \times 2 D]$ & & & & & $x$ \\
\hline & & & 1 & M & $\begin{array}{l}\text { 18.014- } \\
\text { CharType }\end{array}$ & Bytes(18.014) MO [0x30 to $0 \times 39]$ & & & & & $\mathrm{T}$ \\
\hline & & & 1 & M & $\begin{array}{l}\text { NIEM- } \\
\text { 18.014- } \\
\text { CharType }\end{array}$ & Bytes(18.014) MO [0x30 to $0 \times 39,0 \times 2 D]$ & & & & & $x$ \\
\hline & & & 1 & 0 & $\begin{array}{l}\text { 18.993- } \\
\text { CharType }\end{array}$ & $\begin{array}{l}<\text { See Requirment ID: "Field: Source Agency } \\
\text { Name".> }\end{array}$ & $\mathrm{t}-2$ & & & & \\
\hline
\end{tabular}




\begin{tabular}{|c|c|c|c|c|c|c|c|c|c|c|c|}
\hline Req. \# - ID & $\begin{array}{l}\text { Ref. in } \\
\text { Base } \\
\text { Std. }\end{array}$ & $\begin{array}{l}\text { Requirement } \\
\text { Summary }\end{array}$ & $\begin{array}{l}\text { L } \\
\text { e } \\
\text { v } \\
\text { e } \\
\text { I }\end{array}$ & $\begin{array}{l}\mathrm{s} \\
\mathrm{t} \\
\mathrm{a} \\
\mathrm{t} \\
\mathrm{u} \\
\mathrm{s}\end{array}$ & $\begin{array}{l}\text { Assertion } \\
\text { ID }\end{array}$ & $\begin{array}{c}\text { Test } \\
\text { Assertion }\end{array}$ & $\begin{array}{l}\text { Test } \\
\text { Note }\end{array}$ & $\begin{array}{c}\text { Imp. } \\
\text { Support }\end{array}$ & $\begin{array}{l}\text { Supported } \\
\text { Range }\end{array}$ & $\begin{array}{l}\text { Test } \\
\text { Result }\end{array}$ & $\begin{array}{l}\text { Applicable } \\
\text { to }(T, X, B, \\
\left.B^{*}, \text { or } X^{*}\right)\end{array}$ \\
\hline \multicolumn{12}{|c|}{ 8.18: Record Type-18: DNA record } \\
\hline \multirow{8}{*}{$\begin{array}{l}\text { RT18.12 - } \\
\text { Field: } \\
\text { Type17- } \\
\text { Subfield } \\
\text { CharType }\end{array}$} & \multirow[t]{8}{*}{$\begin{array}{l}8.17 \\
\text { Table } 75\end{array}$} & \multirow[t]{8}{*}{$\begin{array}{l}\text { <Table } 75 \text { specifies the Character Type for } \\
\text { each subfield.> }\end{array}$} & 1 & M & $\begin{array}{l}\text { 18.003- } \\
\text { UTY- } \\
\text { CharType }\end{array}$ & Bytes(Infoltem:1 in 18.003) MO [0x30 to $0 \times 39]$ & & & & & $\mathrm{B}^{*}$ \\
\hline & & & 1 & D & $\begin{array}{l}\text { 18.003-LTY- } \\
\text { CharType }\end{array}$ & $\begin{array}{l}\text { Bytes(Infoltem: } 2 \text { in } 18.003) \mathrm{MO}[0 \times 20,0 \times 41 \text { to } \\
0 \times 5 A, 0 \times 61 \text { to } 0 \times 7 A]\end{array}$ & & & & & $\mathrm{B}^{*}$ \\
\hline & & & 1 & $\mathrm{D}$ & $\begin{array}{l}\text { 18.003- } \\
\text { ACC- } \\
\text { CharType }\end{array}$ & 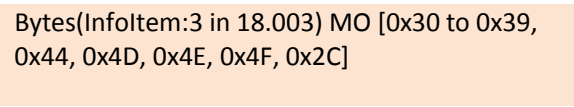 & & & & & $\mathrm{T}$ \\
\hline & & & 1 & $\mathrm{D}$ & $\begin{array}{l}\text { NIEM- } \\
\text { 18.003- } \\
\text { ACC- } \\
\text { CharType }\end{array}$ & $\begin{array}{l}\text { Bytes(XEIm(biom:DNALaboratoryAccreditationLe } \\
\text { velCode) MO [0x30 to 0x39] } \\
\text { OR } \\
\text { Bytes(XEIm(biom:DNALaboratoryAccreditationSc } \\
\text { opeCode) MO } \\
\text { [0x44, 0x4D, 0x4E, 0x4F, 0x2C] }\end{array}$ & & & & & $B^{*}$ \\
\hline & & & 1 & 0 & $\begin{array}{c}\text { 18.003- } \\
\text { [NOO, POC, } \\
\text { ION]- } \\
\text { CharType }\end{array}$ & TRUE & & & & & $\mathrm{B}^{*}$ \\
\hline & & & 1 & 0 & $\begin{array}{l}\text { 18.003- } \\
\text { CSC- } \\
\text { CharType }\end{array}$ & $\begin{array}{l}\text { Bytes(Infoltem: } 6 \text { in } 18.003) \mathrm{MO}[0 \times 20,0 \times 30 \text { to } \\
0 \times 39,0 \times 41 \text { to } 0 \times 5 \mathrm{~A}, 0 \times 61 \text { to } 0 \times 7 \mathrm{~A}]\end{array}$ & & & & & $\mathrm{T}$ \\
\hline & & & 1 & 0 & $\begin{array}{l}\text { NIEM- } \\
\text { 18.003- } \\
\text { CSC- } \\
\text { CharType }\end{array}$ & 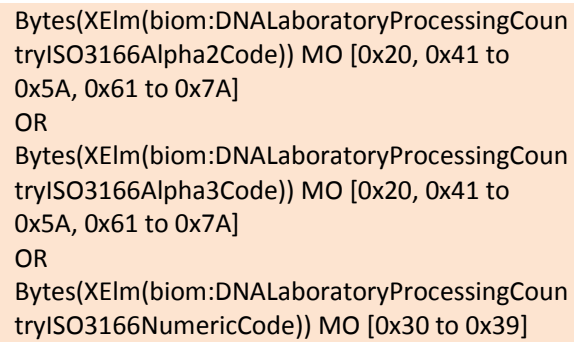 & & & & & $x$ \\
\hline & & & 1 & - & $\begin{array}{c}\text { 18.006- } \\
\text { [DSD,DRA, } \\
\text { SDS]- } \\
\text { CharType }\end{array}$ & $\begin{array}{l}\text { Bytes(Infoltem:1, 7, } 8 \text { in 18.006) MO [0x30 to } \\
\text { 0x39] }\end{array}$ & & & & & $\mathrm{B}^{*}$ \\
\hline
\end{tabular}




\begin{tabular}{|c|c|c|c|c|c|c|c|c|c|c|c|}
\hline Req. \# - ID & $\begin{array}{l}\text { Ref. in } \\
\text { Base } \\
\text { Std. }\end{array}$ & $\begin{array}{l}\text { Requirement } \\
\text { Summary }\end{array}$ & $\begin{array}{l}\mathrm{L} \\
\mathrm{e} \\
\mathrm{v} \\
\mathrm{e} \\
\mathrm{l}\end{array}$ & $\begin{array}{l}\mathrm{s} \\
\mathrm{t} \\
\mathrm{a} \\
\mathrm{t} \\
\mathrm{u} \\
\mathrm{s}\end{array}$ & $\begin{array}{l}\text { Assertion } \\
\text { ID }\end{array}$ & $\begin{array}{c}\text { Test } \\
\text { Assertion }\end{array}$ & $\begin{array}{l}\text { Test } \\
\text { Note }\end{array}$ & $\begin{array}{l}\text { Imp. } \\
\text { Support }\end{array}$ & $\begin{array}{l}\text { Supported } \\
\text { Range }\end{array}$ & $\begin{array}{l}\text { Test } \\
\text { Result }\end{array}$ & $\begin{array}{l}\text { Applicable } \\
\text { to }(\mathrm{T}, \mathrm{X}, \mathrm{B}, \\
\left.\mathrm{B}^{*}, \text { or } \mathrm{X}^{*}\right)\end{array}$ \\
\hline \multicolumn{12}{|c|}{ 8.18: Record Type-18: DNA record } \\
\hline & & & 1 & $\mathrm{O}$ & $\begin{array}{l}\text { 18.006- } \\
\text { [EGP, LLC]- } \\
\text { CharTYpe }\end{array}$ & TRUE & & & & & $\mathrm{B}^{*}$ \\
\hline & & & 1 & 0 & $\begin{array}{l}\text { 18.006- } \\
\text { GID- } \\
\text { CharType }\end{array}$ & $\begin{array}{l}\text { Bytes(Infoltem: } 2 \text { in } 18.006) \mathrm{MO} \text { [0x20, } 0 \times 41 \text { to } \\
0 \times 5 \mathrm{~A}, 0 \times 61 \text { to } 0 \times 7 \mathrm{~A}]\end{array}$ & & & & & $\mathrm{B}^{*}$ \\
\hline & & & 1 & 0 & $\begin{array}{l}\text { 18.006- } \\
\text { [DLC,DOB]- } \\
\text { CharType }\end{array}$ & Bytes(Infoltem:3,4 in 18.006) MO [0x30 to $0 \times 39]$ & & & & & $\mathrm{T}$ \\
\hline & & & 1 & 0 & $\begin{array}{l}\text { NIEM- } \\
\text { 18.006- } \\
\text { [DLC,DOB]- } \\
\text { CharType }\end{array}$ & $\begin{array}{l}\text { Bytes(XEIm(nc:PersonBirthDate), XEIm } \\
\text { biom:DNADonorLastContactDate)) MO [0×30 to } \\
\text { 0x39, 0x2D] }\end{array}$ & & & & & $x$ \\
\hline & & & 1 & - & $\begin{array}{l}\text { 18.009- } \\
\text { [PID, PMI, } \\
\text { SID, PCM]- } \\
\text { CharType }\end{array}$ & TRUE & & & & & $\mathrm{B}^{*}$ \\
\hline & & & 1 & M & $\begin{array}{l}\text { 18.009- } \\
\text { PMS- } \\
\text { CharType }\end{array}$ & $\begin{array}{l}\text { Bytes(Infoltem:3 in } 18.009) \mathrm{MO}[0 \times 20,0 \times 41 \text { to } \\
0 \times 5 \mathrm{~A}, 0 \times 61 \text { to } 0 \times 7 \mathrm{~A}]\end{array}$ & & & & & $\mathrm{B}^{*}$ \\
\hline & & & 1 & 0 & $\begin{array}{l}\text { 18.009- } \\
\text { [FID,MID]- } \\
\text { CharType }\end{array}$ & Bytes(Infoltem:5, 6 in 18.009) MO [0x30 to 0x39] & & & & & $\mathrm{B}^{*}$ \\
\hline & & & 1 & M & $\begin{array}{l}\text { 18.010- } \\
\text { SCT- } \\
\text { CharType }\end{array}$ & Bytes(Infoltem:1 in 18.010$) \mathrm{MO}$ [0x30 to $0 \times 39]$ & & & & & $\mathrm{B}^{*}$ \\
\hline & & & 1 & 0 & $\begin{array}{l}\text { 18.010- } \\
\text { SMO- } \\
\text { CharType }\end{array}$ & $\begin{array}{l}\text { Bytes(Infoltem:2 in } 18.010) \mathrm{MO}[0 \times 20,0 \times 41 \text { to } \\
0 \times 5 \mathrm{~A}, 0 \times 61 \text { to } 0 \times 7 \mathrm{~A}]\end{array}$ & & & & & $\mathrm{B}^{*}$ \\
\hline & & & 1 & M & $\begin{array}{l}\text { 18.011- } \\
\text { CharType }\end{array}$ & $\begin{array}{l}\text { ForEach(SubField in 18.011) } \\
\{ \\
\text { Bytes(Infoltem: } 1 \text { in SubField) MO [0×30 to 0x39] } \\
\}\end{array}$ & & & & & $\mathrm{B}^{*}$ \\
\hline & & & 1 & - & $\begin{array}{l}\text { 18.015- } \\
\text { [PTP, RES]- }\end{array}$ & Bytes(Infoltem:1, 2 in 18.015$) \mathrm{MO}$ [0x30 to $0 \times 39$ ] & & & & & $\mathrm{B}^{*}$ \\
\hline
\end{tabular}




\begin{tabular}{|c|c|c|c|c|c|c|c|c|c|c|c|}
\hline Req. \# - ID & $\begin{array}{l}\text { Ref. in } \\
\text { Base } \\
\text { Std. }\end{array}$ & $\begin{array}{l}\text { Requirement } \\
\text { Summary }\end{array}$ & $\begin{array}{l}\text { L } \\
\text { e } \\
\text { v } \\
\text { e } \\
\text { I }\end{array}$ & $\begin{array}{l}S \\
t \\
a \\
t \\
u \\
s\end{array}$ & $\begin{array}{l}\text { Assertion } \\
\text { ID }\end{array}$ & $\begin{array}{c}\text { Test } \\
\text { Assertion }\end{array}$ & $\begin{array}{l}\text { Test } \\
\text { Note }\end{array}$ & $\begin{array}{l}\text { Imp. } \\
\text { Support }\end{array}$ & $\begin{array}{l}\text { Supported } \\
\text { Range }\end{array}$ & $\begin{array}{l}\text { Test } \\
\text { Result }\end{array}$ & $\begin{array}{l}\text { Applicable } \\
\text { to }(\mathrm{T}, \mathrm{X}, \mathrm{B}, \\
\left.\mathrm{B}^{*}, \text { or } \mathrm{X}^{*}\right)\end{array}$ \\
\hline \multicolumn{12}{|c|}{ 8.18: Record Type-18: DNA record } \\
\hline & & & & & CharType & & & & & & \\
\hline & & & 1 & - & $\begin{array}{c}\text { 18.015- } \\
\text { [PRF, SUP, } \\
\text { DPC]- } \\
\text { CharType }\end{array}$ & TRUE & & & & & $B^{*}$ \\
\hline & & & 1 & M & $\begin{array}{l}\text { 18.016- } \\
\text { [DST, DLR, } \\
\text { ALL, LAI, } \\
\text { PCDT, KID]- } \\
\text { CharType }\end{array}$ & 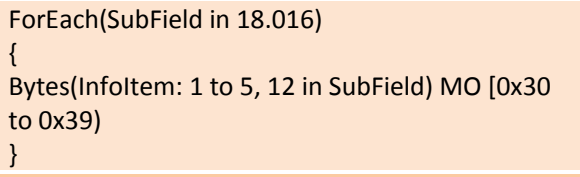 & & & & & $B^{*}$ \\
\hline & & & 1 & D & $\begin{array}{c}\text { 18.016- } \\
\text { [AL1, AL2, } \\
\text { AL3]- } \\
\text { CharType }\end{array}$ & 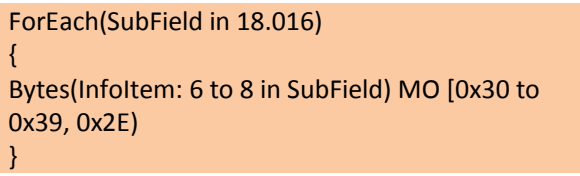 & & & & & $B^{*}$ \\
\hline & & & 1 & - & $\begin{array}{l}\text { 18.016- } \\
\text { [BID, ECR, } \\
\text { LCR, KNM, } \\
\text { KMF, KDS]- } \\
\text { CharType }\end{array}$ & TRUE & & & & & $B^{*}$ \\
\hline & & & 1 & M & $\begin{array}{l}\text { 18.017- } \\
\text { [MT1, } \\
\text { MT2]- } \\
\text { CharType }\end{array}$ & $\begin{array}{l}\text { Bytes(Infoltem: } 1,2 \text { in } 18.017) \mathrm{MO}[0 \times 20,0 \times 41 \text { to } \\
0 \times 5 \mathrm{~A}, 0 \times 61 \text { to } 0 \times 7 \mathrm{~A}, 0 \times 2 \mathrm{D})\end{array}$ & & & & & $\mathrm{B}^{*}$ \\
\hline & & & 1 & M & $\begin{array}{l}\text { 18.017- } \\
\text { [BSP, BEP, } \\
\text { BCA, BCG, } \\
\text { BCC, BCT]- } \\
\text { CharType }\end{array}$ & $\begin{array}{l}\text { Bytes(Infoltem: } 3 \text { to } 8 \text { in } 18.017 \text { ) MO [0x30 to } \\
\text { 0x39) }\end{array}$ & & & & & $B^{*}$ \\
\hline & & & 1 & M & $\begin{array}{l}\text { 18.018- } \\
\text { CharType }\end{array}$ & TRUE & & & & & $\mathrm{B}^{*}$ \\
\hline & & & 1 & M & $\begin{array}{l}\text { 18.019- } \\
\text { [EIR, EST, } \\
\text { IDD]- } \\
\text { CharType }\end{array}$ & TRUE & & & & & $\mathrm{B}^{*}$ \\
\hline
\end{tabular}




\begin{tabular}{|c|c|c|c|c|c|c|c|c|c|c|c|}
\hline Req. \# - ID & $\begin{array}{l}\text { Ref. in } \\
\text { Base } \\
\text { Std. }\end{array}$ & $\begin{array}{l}\text { Requirement } \\
\text { Summary }\end{array}$ & $\begin{array}{l}\text { L } \\
\text { e } \\
\text { v } \\
\text { e } \\
\text { I }\end{array}$ & $\begin{array}{l}\mathrm{s} \\
\mathrm{t} \\
\mathrm{a} \\
\mathrm{t} \\
\mathrm{u} \\
\mathrm{s}\end{array}$ & $\begin{array}{l}\text { Assertion } \\
\text { ID }\end{array}$ & $\begin{array}{c}\text { Test } \\
\text { Assertion }\end{array}$ & $\begin{array}{l}\text { Test } \\
\text { Note }\end{array}$ & $\begin{array}{c}\text { Imp. } \\
\text { Support }\end{array}$ & $\begin{array}{l}\text { Supported } \\
\text { Range }\end{array}$ & $\begin{array}{c}\text { Test } \\
\text { Result }\end{array}$ & $\begin{array}{l}\text { Applicable } \\
\text { to }(\mathrm{T}, \mathrm{X}, \mathrm{B}, \\
\left.\mathrm{B}^{*}, \text { or } \mathrm{X}^{*}\right)\end{array}$ \\
\hline \multicolumn{12}{|c|}{ 8.18: Record Type-18: DNA record } \\
\hline & & & 1 & - & $\begin{array}{l}\text { 18.019- } \\
\text { [ELPD, } \\
\text { EPS]- } \\
\text { CharType }\end{array}$ & 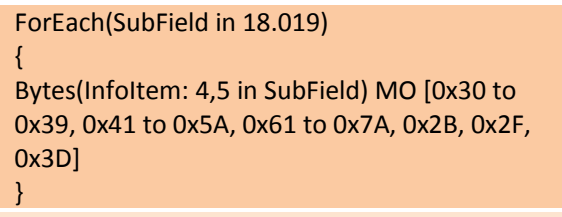 & & & & & $B^{*}$ \\
\hline & & & 1 & M & $\begin{array}{l}\text { 18.021- } \\
\text { GLR- } \\
\text { CharType }\end{array}$ & $\begin{array}{l}\text { ForEach(SubField in } 18.021 \text { ) } \\
\{ \\
\text { Bytes(Infoltem:1 in SubField) MO [0×30 to } 0 \times 39] \\
\}\end{array}$ & & & & & $\mathrm{B}^{*}$ \\
\hline & & & 1 & M & $\begin{array}{l}\text { 18.021- } \\
\text { ALP- } \\
\text { CharType }\end{array}$ & $\begin{array}{l}\text { ForEach(SubField in 18.021) } \\
\{ \\
\text { Bytes(Infoltem:2 in SubField) MO [0x2C, 0x2E, } \\
\text { Ox30 to } 0 \times 39] \\
\}\end{array}$ & & & & & $B^{*}$ \\
\hline & & & 1 & M & $\begin{array}{l}\text { 18.021- } \\
\text { GNW- } \\
\text { CharType }\end{array}$ & $\begin{array}{l}\text { ForEach(SubField in 18.021) } \\
\{ \\
\text { Bytes(Infoltem:3 in SubField) MO [0×2E, } 0 \times 30 \text { to } \\
\text { Ox39] } \\
\}\end{array}$ & & & & & $\mathrm{B}^{*}$ \\
\hline & & & 1 & M & $\begin{array}{l}\text { 18.023- } \\
\text { [LIR, LST, } \\
\text { LDD]- } \\
\text { CharType }\end{array}$ & TRUE & & & & & $B^{*}$ \\
\hline & & & 1 & - & $\begin{array}{l}\text { 18.023- } \\
\text { [LEPD, LES]- } \\
\text { CharType }\end{array}$ & $\begin{array}{l}\text { ForEach(SubField in } 18.023 \text { ) } \\
\{ \\
\text { Bytes(Infoltem: } 4,5 \text { in SubField) MO [0×30 to } \\
0 \times 39,0 \times 41 \text { to } 0 \times 5 \mathrm{~A}, 0 \times 61 \text { to } 0 \times 7 \mathrm{~A}, 0 \times 2 \mathrm{~B}, 0 \times 2 \mathrm{~F} \text {, } \\
0 \times 3 \mathrm{D}] \\
\}\end{array}$ & & & & & $B^{*}$ \\
\hline & & & 1 & M & $\begin{array}{l}\text { 18.902- } \\
\text { [NAV, } \\
\text { OWN, } \\
\text { PRO]- } \\
\text { CharType }\end{array}$ & TRUE & & & & & $B^{*}$ \\
\hline
\end{tabular}




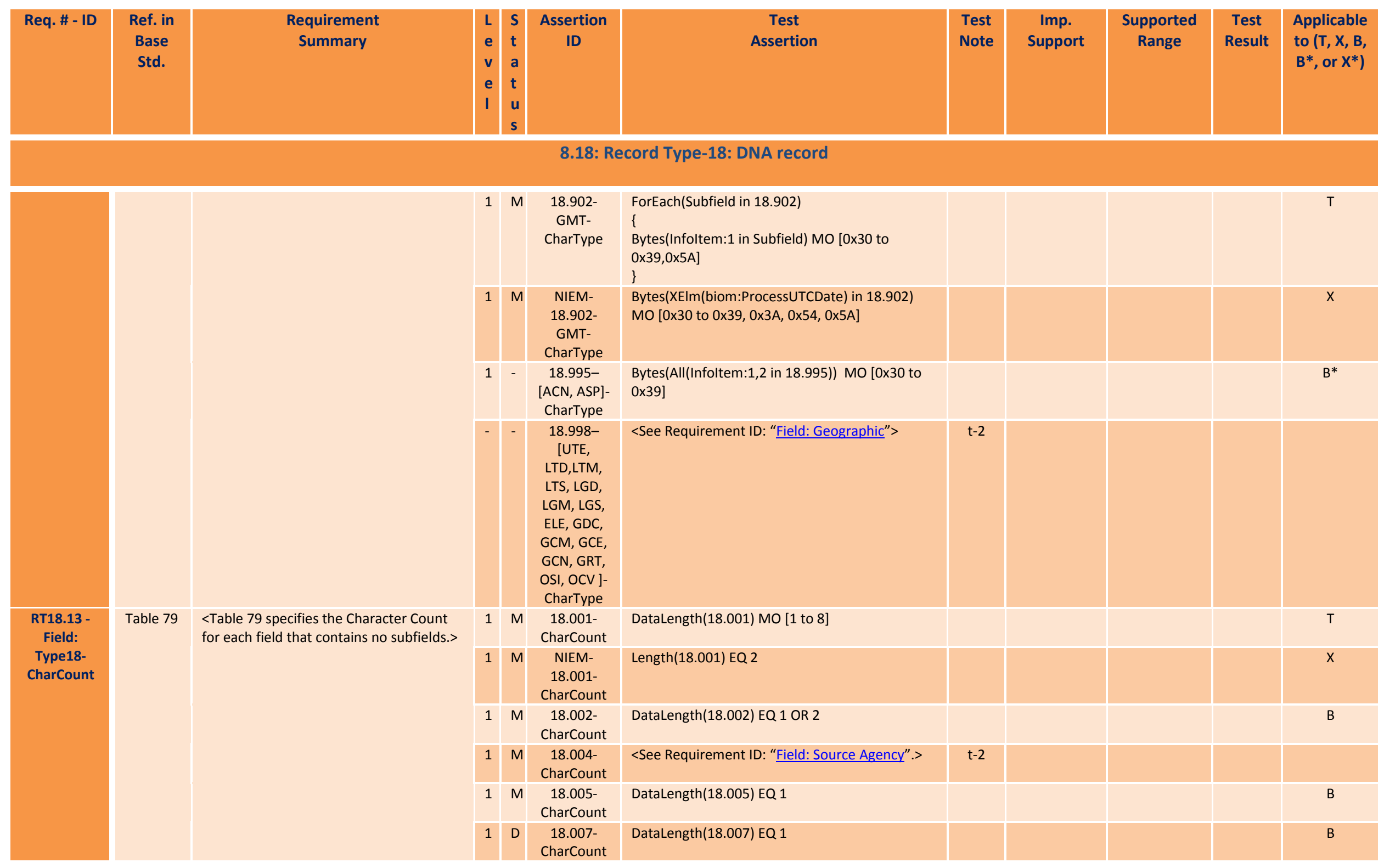




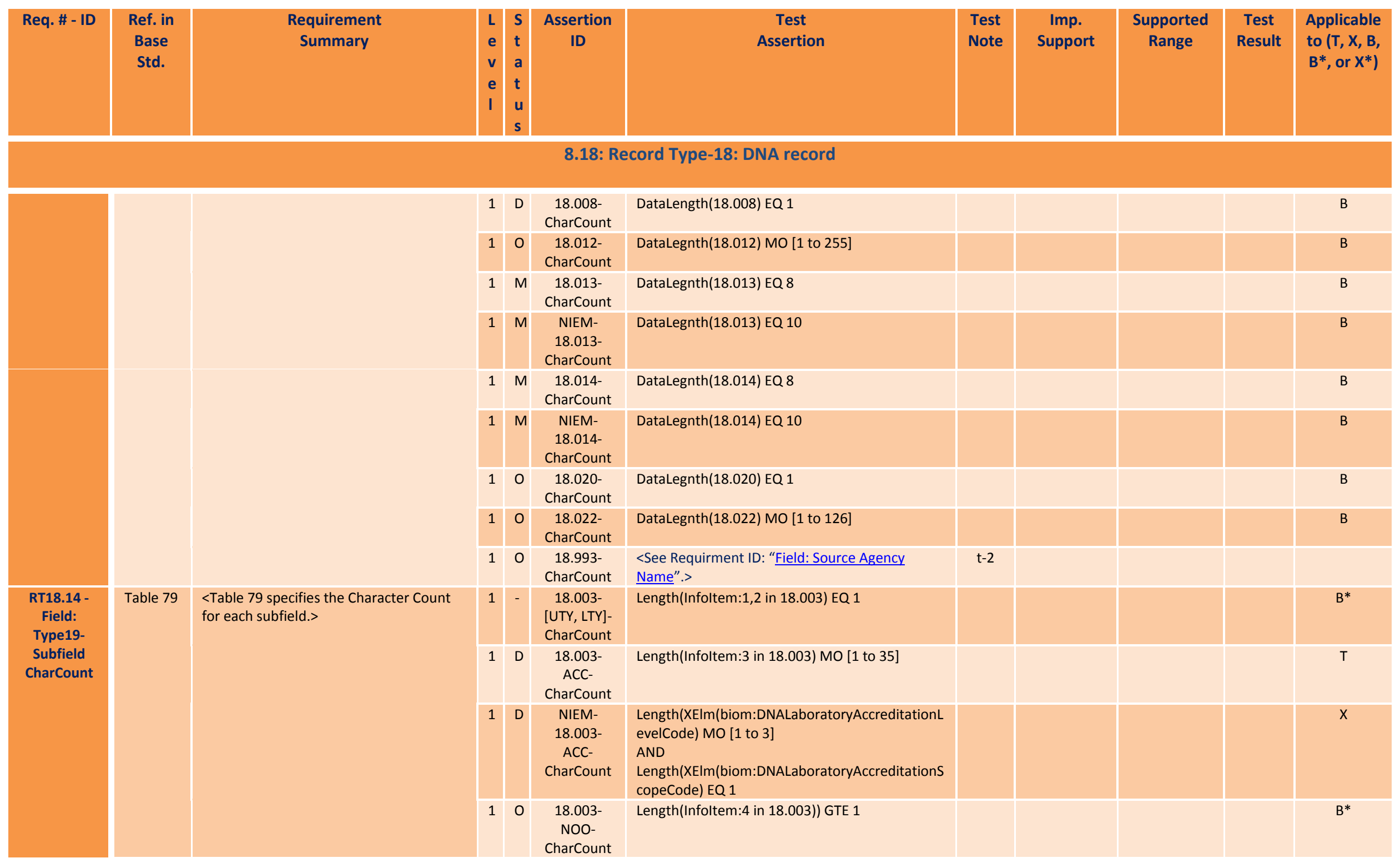




\begin{tabular}{|c|c|c|c|c|c|c|c|c|c|c|c|}
\hline Req. \# - ID & $\begin{array}{c}\text { Ref. in } \\
\text { Base } \\
\text { Std. }\end{array}$ & $\begin{array}{l}\text { Requirement } \\
\text { Summary }\end{array}$ & $\begin{array}{l}\mathrm{L} \\
\mathrm{e} \\
\mathrm{v} \\
\mathrm{e} \\
\mathrm{I}\end{array}$ & $\begin{array}{l}\mathrm{s} \\
\mathrm{t} \\
\mathrm{a} \\
\mathrm{t} \\
\mathrm{u} \\
\mathrm{s}\end{array}$ & $\begin{array}{l}\text { Assertion } \\
\text { ID }\end{array}$ & $\begin{array}{c}\text { Test } \\
\text { Assertion }\end{array}$ & $\begin{array}{l}\text { Test } \\
\text { Note }\end{array}$ & $\begin{array}{l}\text { Imp. } \\
\text { Support }\end{array}$ & $\begin{array}{l}\text { Supported } \\
\text { Range }\end{array}$ & $\begin{array}{c}\text { Test } \\
\text { Result }\end{array}$ & $\begin{array}{l}\text { Applicable } \\
\text { to }(\mathrm{T}, \mathrm{X}, \mathrm{B}, \\
\left.\mathrm{B}^{*} \text {, or } \mathrm{X}^{*}\right)\end{array}$ \\
\hline
\end{tabular}

\subsection{8: Record Type-18: DNA record}

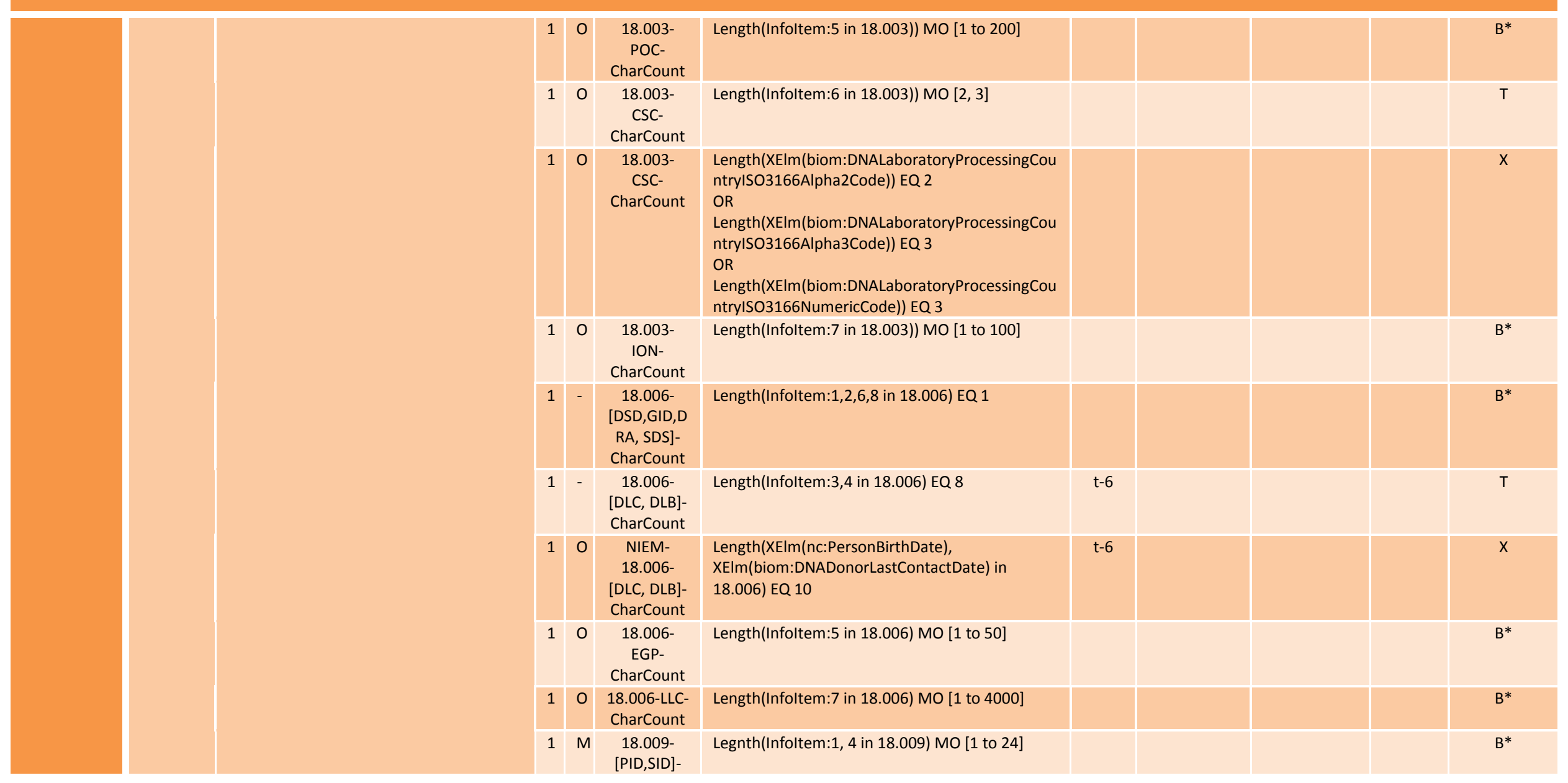




\begin{tabular}{|c|c|c|c|c|c|c|c|c|c|c|c|}
\hline Req. \# - ID & $\begin{array}{l}\text { Ref. in } \\
\text { Base } \\
\text { Std. }\end{array}$ & $\begin{array}{l}\text { Requirement } \\
\text { Summary }\end{array}$ & $\begin{array}{l}\text { L } \\
\text { e } \\
\text { v } \\
\text { e } \\
\text { I }\end{array}$ & $\begin{array}{l}\mathrm{S} \\
\mathrm{t} \\
\mathrm{a} \\
\mathrm{t} \\
\mathrm{u} \\
\mathrm{s}\end{array}$ & $\begin{array}{l}\text { Assertion } \\
\text { ID }\end{array}$ & $\begin{array}{c}\text { Test } \\
\text { Assertion }\end{array}$ & $\begin{array}{l}\text { Test } \\
\text { Note }\end{array}$ & $\begin{array}{l}\text { Imp. } \\
\text { Support }\end{array}$ & $\begin{array}{l}\text { Supported } \\
\text { Range }\end{array}$ & $\begin{array}{c}\text { Test } \\
\text { Result }\end{array}$ & $\begin{array}{l}\text { Applicable } \\
\text { to }(T, X, B, \\
\left.B^{*}, \text { or } X^{*}\right)\end{array}$ \\
\hline
\end{tabular}

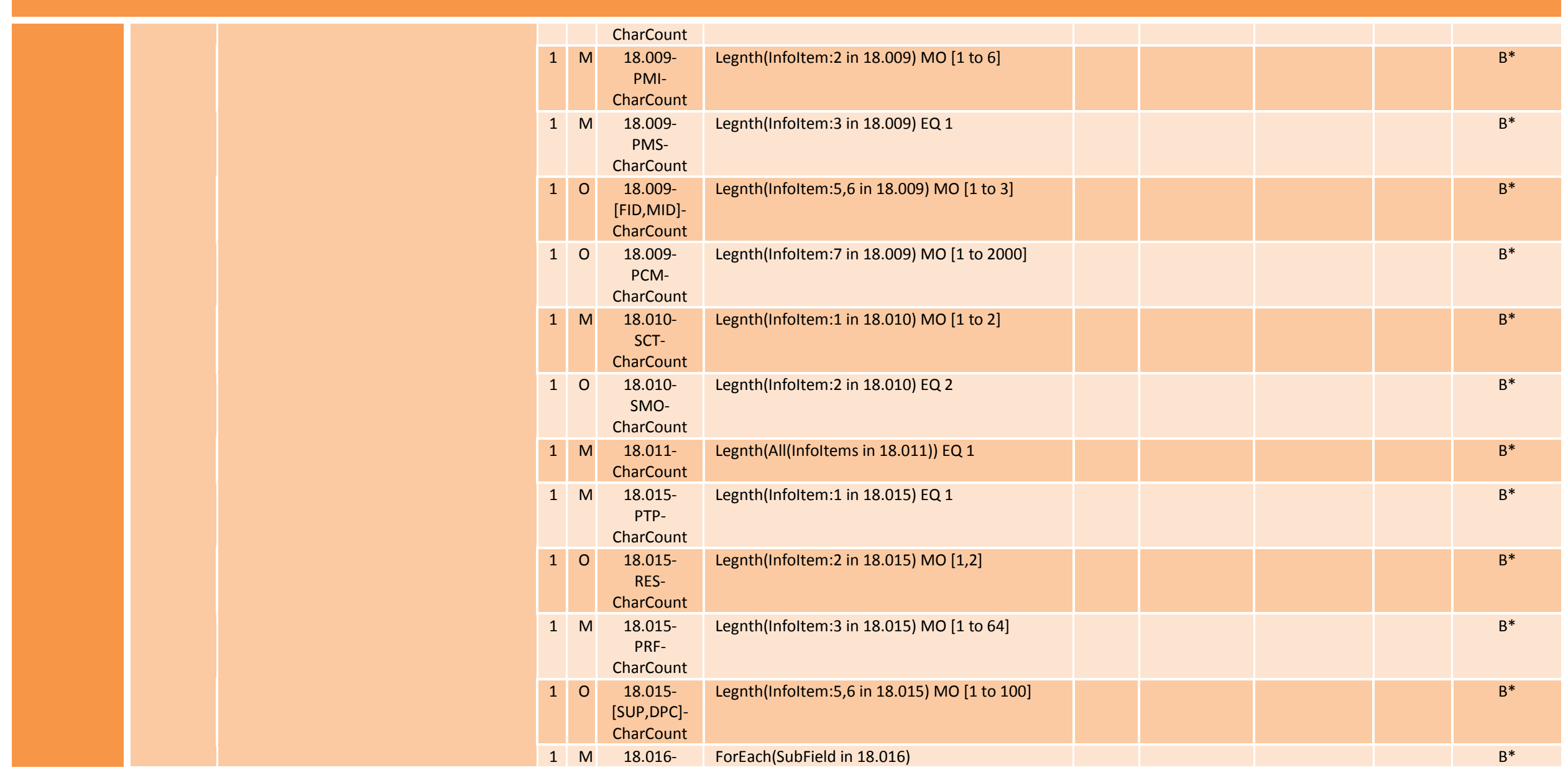




\begin{tabular}{|c|c|c|c|c|c|c|c|c|c|c|c|}
\hline Req. \# - ID & $\begin{array}{l}\text { Ref. in } \\
\text { Base } \\
\text { Std. }\end{array}$ & $\begin{array}{l}\text { Requirement } \\
\text { Summary }\end{array}$ & $\begin{array}{l}\text { L } \\
\text { e } \\
\text { v } \\
\text { e } \\
\text { I }\end{array}$ & $\begin{array}{l}\mathrm{s} \\
\mathrm{t} \\
\mathrm{a} \\
\mathrm{t} \\
\mathrm{u} \\
\mathrm{s}\end{array}$ & $\begin{array}{l}\text { Assertion } \\
\text { ID }\end{array}$ & $\begin{array}{c}\text { Test } \\
\text { Assertion }\end{array}$ & $\begin{array}{l}\text { Test } \\
\text { Note }\end{array}$ & $\begin{array}{l}\text { Imp. } \\
\text { Support }\end{array}$ & $\begin{array}{l}\text { Supported } \\
\text { Range }\end{array}$ & $\begin{array}{l}\text { Test } \\
\text { Result }\end{array}$ & $\begin{array}{l}\text { Applicable } \\
\text { to }(\mathrm{T}, \mathrm{X}, \mathrm{B}, \\
\left.\mathrm{B}^{*}, \text { or } \mathrm{X}^{*}\right)\end{array}$ \\
\hline \multicolumn{12}{|c|}{ 8.18: Record Type-18: DNA record } \\
\hline & & & & & $\begin{array}{l}\text { [DST,ALL,LA } \\
\text { I,PCDT]- } \\
\text { CharCount }\end{array}$ & $\begin{array}{l}\{ \\
\text { Legnth(Infoltem:1,3,4,5 in SubField) EQ } 1\end{array}$ & & & & & \\
\hline & & & 1 & M & $\begin{array}{l}\text { 18.016- } \\
\text { [DLR, KID]- } \\
\text { CharCount }\end{array}$ & $\begin{array}{l}\text { ForEach(SubField in } 18.016) \\
\{ \\
\text { Legnth(Infoltem:2,12 in SubField) MO [1 to 3] } \\
\}\end{array}$ & & & & & $B^{*}$ \\
\hline & & & 1 & $\mathrm{D}$ & $\begin{array}{l}\text { 18.016- } \\
\text { [AL1, AL2, } \\
\text { AL3]- } \\
\text { CharCount }\end{array}$ & $\begin{array}{l}\text { ForEach(SubField in 18.016) } \\
\{ \\
\text { Legnth(Infoltem:6,7,8 in SubField) MO [1 to 4] } \\
\}\end{array}$ & & & & & $\mathrm{B}^{*}$ \\
\hline & & & 1 & - & $\begin{array}{l}\text { 18.016- } \\
\text { [BID, KNM, } \\
\text { KMF]- } \\
\text { CharCount }\end{array}$ & $\begin{array}{l}\text { ForEach(SubField in } 18.016) \\
\{ \\
\text { Legnth(Infoltem:9,13,14 in SubField) MO [1 to } \\
32] \\
\}\end{array}$ & & & & & $\mathrm{B}^{*}$ \\
\hline & & & 1 & 0 & $\begin{array}{l}\text { 18.016- } \\
{[E C R, L C R]-} \\
\text { CharCount }\end{array}$ & $\begin{array}{l}\text { ForEach(SubField in 18.016) } \\
\{ \\
\text { Legnth(Infoltem:10,11 in SubField) MO [1 to 8] } \\
\}\end{array}$ & & & & & $\mathrm{B}^{*}$ \\
\hline & & & 1 & $\mathrm{D}$ & $\begin{array}{l}\text { 18.016- } \\
\text { KDS- } \\
\text { CharCount }\end{array}$ & $\begin{array}{l}\text { ForEach(SubField in 18.016) } \\
\{ \\
\text { Legnth(Infoltem:15 in SubField) MO [1 to } 128] \\
\}\end{array}$ & & & & & $\mathrm{B}^{*}$ \\
\hline & & & 1 & M & $\begin{array}{l}\text { 18.017- } \\
\text { MT1- } \\
\text { CharCount }\end{array}$ & Legnth(Infoltem:1 in 18.017) MO [546 to 646] & & & & & $\mathrm{B}^{*}$ \\
\hline & & & 1 & M & $\begin{array}{l}\text { 18.017- } \\
\text { MT1- } \\
\text { CharCount }\end{array}$ & Legnth(Infoltem:2 in 18.017) MO [576 to 976] & & & & & $\mathrm{B}^{*}$ \\
\hline & & & 1 & M & $\begin{array}{l}\text { 18.017- } \\
\text { [BSP, BEP]- } \\
\text { CharCount }\end{array}$ & Legnth(Infoltem:3,4 in 18.017) MO [1 to 5] & & & & & $\mathrm{B}^{*}$ \\
\hline & & & 1 & M & $\begin{array}{c}\text { 18.017- } \\
\text { [BCA, BCG, }\end{array}$ & Legnth(Infoltem:5,6,7,8 in 18.017) MO [1,2] & & & & & $\mathrm{B}^{*}$ \\
\hline
\end{tabular}




\begin{tabular}{|c|c|c|c|c|c|c|c|c|c|c|c|}
\hline Req. \# - ID & $\begin{array}{l}\text { Ref. in } \\
\text { Base } \\
\text { Std. }\end{array}$ & $\begin{array}{l}\text { Requirement } \\
\text { Summary }\end{array}$ & $\begin{array}{l}\mathrm{L} \\
\mathrm{e} \\
\mathrm{v} \\
\mathrm{e} \\
\mathrm{l}\end{array}$ & $\begin{array}{l}\mathrm{s} \\
\mathrm{t} \\
\mathrm{a} \\
\mathrm{t} \\
\mathrm{u} \\
\mathrm{s}\end{array}$ & $\begin{array}{l}\text { Assertion } \\
\text { ID }\end{array}$ & $\begin{array}{c}\text { Test } \\
\text { Assertion }\end{array}$ & $\begin{array}{l}\text { Test } \\
\text { Note }\end{array}$ & $\begin{array}{l}\text { Imp. } \\
\text { Support }\end{array}$ & $\begin{array}{l}\text { Supported } \\
\text { Range }\end{array}$ & $\begin{array}{l}\text { Test } \\
\text { Result }\end{array}$ & $\begin{array}{l}\text { Applicable } \\
\text { to }(\mathrm{T}, \mathrm{X}, \mathrm{B}, \\
\left.\mathrm{B}^{*}, \text { or } \mathrm{X}^{*}\right)\end{array}$ \\
\hline \multicolumn{12}{|c|}{ 8.18: Record Type-18: DNA record } \\
\hline & & & & & $\begin{array}{l}\text { BCC, BCT]- } \\
\text { CharCount }\end{array}$ & & & & & & \\
\hline & & & 1 & M & $\begin{array}{c}\text { 18.018- } \\
\text { CharCount }\end{array}$ & TRUE & & & & & $\mathrm{B}^{*}$ \\
\hline & & & 1 & M & $\begin{array}{l}\text { 18.019-EIR- } \\
\text { CharCount }\end{array}$ & $\begin{array}{l}\text { ForEach(SubField in 18.019) } \\
\{ \\
\text { Legnth(Infoltem:1 in SubField) MO [1 to 8] } \\
\}\end{array}$ & & & & & $\mathrm{B}^{*}$ \\
\hline & & & 1 & M & $\begin{array}{l}\text { 18.019-EST- } \\
\text { CharCount }\end{array}$ & $\begin{array}{l}\text { ForEach(SubField in 18.019) } \\
\{ \\
\text { Legnth(Infoltem: } 2 \text { in SubField) MO [1 to 4] } \\
\}\end{array}$ & & & & & $\mathrm{B}^{*}$ \\
\hline & & & 1 & M & $\begin{array}{l}\text { 18.019- } \\
\text { IDD- } \\
\text { CharCount }\end{array}$ & $\begin{array}{l}\text { ForEach(SubField in 18.019) } \\
\{ \\
\text { Legnth(Infoltem: } 3 \text { in SubField) MO [1 to 200] } \\
\}\end{array}$ & & & & & $\mathrm{B}^{*}$ \\
\hline & & & 1 & - & $\begin{array}{l}\text { 18.019- } \\
\text { [ELPD,EPS]- } \\
\text { CharCount }\end{array}$ & $\begin{array}{l}\text { ForEach(SubField in 18.019) } \\
\{ \\
\text { Legnth(Infoltem:4,5 in SubField) GTE } 2 \\
\}\end{array}$ & & & & & $\mathrm{B}^{*}$ \\
\hline & & & 1 & M & $\begin{array}{l}\text { 18.021- } \\
\text { GLR- } \\
\text { CharCount }\end{array}$ & $\begin{array}{l}\text { ForEach(SubField in 18.021) } \\
\{ \\
\text { Legnth(Infoltem:1 in SubField) MO [1 to3] } \\
\}\end{array}$ & & & & & $\mathrm{B}^{*}$ \\
\hline & & & 1 & M & $\begin{array}{l}\text { 18.021- } \\
\text { ALP- } \\
\text { CharCount }\end{array}$ & $\begin{array}{l}\text { ForEach(SubField in 18.021) } \\
\{ \\
\text { Legnth(Infoltem:2 in SubField) MO [3 to 9] } \\
\}\end{array}$ & & & & & $\mathrm{B}^{*}$ \\
\hline & & & 1 & M & $\begin{array}{l}\text { 18.021- } \\
\text { GNW- } \\
\text { CharCount }\end{array}$ & $\begin{array}{l}\text { ForEach(SubField in 18.021) } \\
\{ \\
\text { Legnth(Infoltem:3 in SubField) MO [1 to5] } \\
\}\end{array}$ & & & & & $\mathrm{B}^{*}$ \\
\hline & & & 1 & M & $\begin{array}{l}\text { 18.023-LIR- } \\
\text { CharCount }\end{array}$ & $\begin{array}{l}\text { ForEach(SubField in 18.023) } \\
\{ \\
\text { Legnth(Infoltem:1 in SubField) MO [1 to 8] }\end{array}$ & & & & & $\mathrm{B}^{*}$ \\
\hline
\end{tabular}




\begin{tabular}{|c|c|c|c|c|c|c|c|c|c|c|c|}
\hline Req. \# - ID & $\begin{array}{c}\text { Ref. in } \\
\text { Base } \\
\text { Std. }\end{array}$ & $\begin{array}{c}\text { Requirement } \\
\text { Summary }\end{array}$ & $\begin{array}{l}\mathrm{L} \\
\mathrm{e} \\
\mathrm{v} \\
\mathrm{e} \\
\mathrm{I}\end{array}$ & $\begin{array}{l}S \\
t \\
a \\
t \\
u \\
s\end{array}$ & $\begin{array}{l}\text { Assertion } \\
\text { ID }\end{array}$ & $\begin{array}{c}\text { Test } \\
\text { Assertion }\end{array}$ & $\begin{array}{l}\text { Test } \\
\text { Note }\end{array}$ & $\begin{array}{c}\text { Imp. } \\
\text { Support }\end{array}$ & $\begin{array}{c}\text { Supported } \\
\text { Range }\end{array}$ & $\begin{array}{c}\text { Test } \\
\text { Result }\end{array}$ & $\begin{array}{l}\text { Applicable } \\
\text { to }(T, X, B, \\
\left.B^{*}, \text { or } X^{*}\right)\end{array}$ \\
\hline
\end{tabular}

\subsection{8: Record Type-18: DNA record}

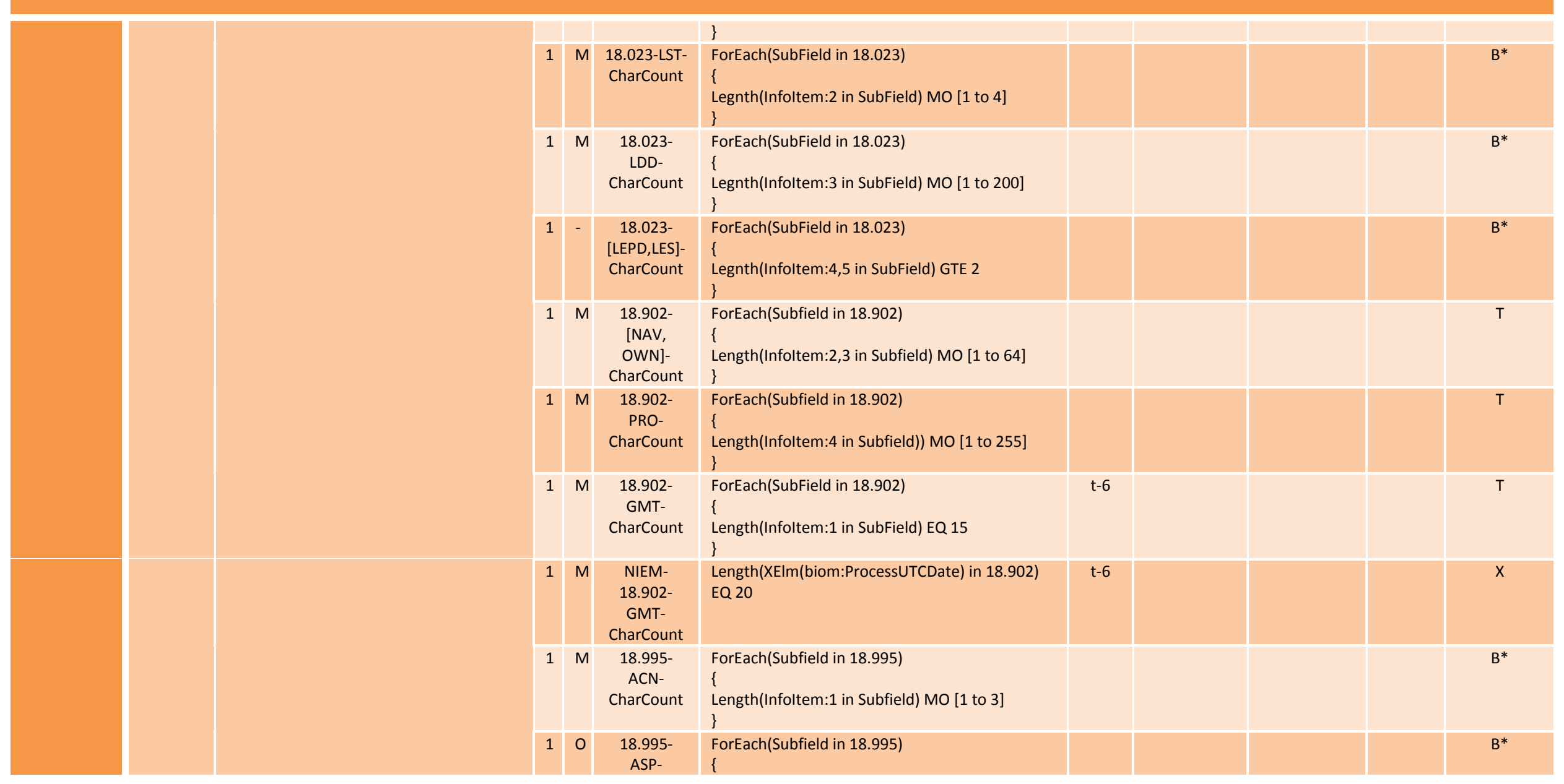




\begin{tabular}{|c|c|c|c|c|c|c|c|c|c|c|c|}
\hline Req. \# - ID & $\begin{array}{l}\text { Ref. in } \\
\text { Base } \\
\text { Std. }\end{array}$ & $\begin{array}{l}\text { Requirement } \\
\text { Summary }\end{array}$ & $\begin{array}{l}\text { L } \\
\text { e } \\
\text { v } \\
\text { e } \\
\text { I }\end{array}$ & $\begin{array}{l}\mathrm{s} \\
\mathrm{t} \\
\mathrm{a} \\
\mathrm{t} \\
\mathrm{u} \\
\mathrm{s}\end{array}$ & $\begin{array}{l}\text { Assertion } \\
\text { ID }\end{array}$ & $\begin{array}{c}\text { Test } \\
\text { Assertion }\end{array}$ & $\begin{array}{l}\text { Test } \\
\text { Note }\end{array}$ & $\begin{array}{c}\text { Imp. } \\
\text { Support }\end{array}$ & $\begin{array}{l}\text { Supported } \\
\text { Range }\end{array}$ & $\begin{array}{c}\text { Test } \\
\text { Result }\end{array}$ & $\begin{array}{l}\text { Applicable } \\
\text { to }(\mathrm{T}, \mathrm{X}, \mathrm{B} \text {, } \\
\left.\mathrm{B}^{*}, \text { or } \mathrm{X}^{*}\right)\end{array}$ \\
\hline \multicolumn{12}{|c|}{ 8.18: Record Type-18: DNA record } \\
\hline & & & & & CharCount & $\begin{array}{l}\text { Length(Infoltem:2 in Subfield) MO }[1,2] \\
\}\end{array}$ & & & & & \\
\hline & & & - & 0 & $\begin{array}{c}\text { 18.998-[ } \\
\text { UTE, } \\
\text { LTD,LTM, } \\
\text { LTS, LGD, } \\
\text { LGM, LGS, } \\
\text { ELE, GDC, } \\
\text { GCM, GCE, } \\
\text { GCN, GRT, } \\
\text { OSI, OCV]- } \\
\text { CharCount }\end{array}$ & <See Requirement ID: "Field: Geographic"> & $\mathrm{t}-2$ & & & & \\
\hline \multirow[t]{3}{*}{$\begin{array}{l}\text { RT18.15 - } \\
\text { Field: } \\
\text { Type18-Field } \\
\text { Occurrence }\end{array}$} & \multirow[t]{3}{*}{ Table 79} & \multirow[t]{3}{*}{$\begin{array}{l}<\text { Table } 79 \text { specifies the Field Occurrence } \\
\text { for each field.> }\end{array}$} & 1 & - & $\begin{array}{c}18 .[024 \text { to } \\
199,901,90 \\
3 \text { to } 992, \\
994,996, \\
997,999]- \\
\text { Occurrence }\end{array}$ & $\begin{array}{l}\text { Count(18.[ } 024 \text { to } 199,901,903 \text { to } 992,994,996 \text {, } \\
\text { 997, 999]) EQ } 0\end{array}$ & & & & & B \\
\hline & & & 1 & M & $\begin{array}{c}\text { 87.[001 to } \\
006,010, \\
011,013 \text { to } \\
015])- \\
\text { Occurrence }\end{array}$ & $\begin{array}{l}\text { Count(18.[ } 001 \text { to } 006,010,011,013 \text { to } 015]) E Q \\
1\end{array}$ & & & & & B \\
\hline & & & 1 & - & $\begin{array}{c}18 .[007 \text { to } \\
009,012, \\
016 \text { to } 023, \\
902,993, \\
995,998]-- \\
\text { Occurrence }\end{array}$ & $\begin{array}{l}\text { Count }(18 .[007 \text { to } 009,012,016 \text { to } 023,902 \text {, } \\
993,995,998]) \text { LTE } 1\end{array}$ & & & & & B \\
\hline $\begin{array}{l}\text { RT18.16 - } \\
\text { Field: } \\
\text { 18.001- } \\
\text { Record }\end{array}$ & $\begin{array}{l}\text { 8.18.1 } \\
\text { Table } 79\end{array}$ & $\begin{array}{l}\text { Field } 18.001 \text { Record header. In Traditional } \\
\text { encoding, this field contains the record } \\
\text { length in bytes (including all information } \\
\text { separators) }\end{array}$ & & M & $\begin{array}{l}\text { 18.001- } \\
\text { Record } \\
\text { Header }\end{array}$ & $\begin{array}{l}\text { <See Requirement ID “Field: xx.001-Record } \\
\text { Header"> }\end{array}$ & $\mathrm{t}-2$ & & & & \\
\hline $\begin{array}{l}\text { Header } \\
\text { Value }\end{array}$ & $\begin{array}{l}8.18 .1 \\
\text { C.10.16 }\end{array}$ & $\begin{array}{l}\text { The XML name for the Type- } 18 \text { record is } \\
<\text { itl:PackageDNARecord>, and its }\end{array}$ & 1 & M & $\begin{array}{l}\text { NIEM- } \\
18.001-\end{array}$ & $\begin{array}{l}\text { ForEach(XElm(itl:PackageDNARecord) } \\
\{\end{array}$ & & & & & $x$ \\
\hline
\end{tabular}




\begin{tabular}{|c|c|c|c|c|c|c|c|c|c|c|c|}
\hline Req. \# - ID & $\begin{array}{l}\text { Ref. in } \\
\text { Base } \\
\text { Std. }\end{array}$ & $\begin{array}{l}\text { Requirement } \\
\text { Summary }\end{array}$ & $\begin{array}{l}\text { L } \\
\text { e } \\
\text { v } \\
\text { e } \\
\text { I }\end{array}$ & $\begin{array}{l}\mathrm{S} \\
\mathrm{t} \\
\mathrm{a} \\
\mathrm{t} \\
\mathrm{u} \\
\mathrm{s}\end{array}$ & $\begin{array}{l}\text { Assertion } \\
\text { ID }\end{array}$ & $\begin{array}{c}\text { Test } \\
\text { Assertion }\end{array}$ & $\begin{array}{l}\text { Test } \\
\text { Note }\end{array}$ & $\begin{array}{l}\text { Imp. } \\
\text { Support }\end{array}$ & $\begin{array}{l}\text { Supported } \\
\text { Range }\end{array}$ & $\begin{array}{l}\text { Test } \\
\text { Result }\end{array}$ & $\begin{array}{l}\text { Applicable } \\
\text { to }(T, X, B \text {, } \\
\left.B^{*} \text {, or } X^{*}\right)\end{array}$ \\
\hline \multicolumn{12}{|c|}{ 8.18: Record Type-18: DNA record } \\
\hline & & $\begin{array}{l}\text { <biom:RecordCategoryCode> element } \\
\text { shall have a value of " } 18 \text { ". }\end{array}$ & & & Value & $\begin{array}{l}\{X E I m(\text { biom:RecordCategoryCode) }\} \text { EQ ASCII(18) } \\
\}\end{array}$ & & & & & \\
\hline $\begin{array}{l}\text { RT18.17 - } \\
\text { Field: } \\
\text { 18.002- } \\
\text { Information } \\
\text { Designation } \\
\text { Character } \\
\text { Value }\end{array}$ & $\begin{array}{c}\text { 8.18.2, } \\
\text { Table 79, } \\
7.3 .1\end{array}$ & $\begin{array}{l}\text { This mandatory field shall contain the IDC } \\
\text { assigned to this Type-18 record as listed } \\
\text { in the information item IDC for this record } \\
\text { in Field } 1.003 \text { Transaction content/CNT. }\end{array}$ & & M & 18.002-IDC & $\begin{array}{l}<\text { See Requirement IDs "Field: } x x .002-I D C \text { " and } \\
\text { "Field: } 1.003-\text { Transaction Content Subfield } 2 \text { IDC } \\
\underline{\text { Matches" }} \text { > }\end{array}$ & $\mathrm{t}-2$ & & & & \\
\hline \multirow{4}{*}{$\begin{array}{l}\text { RT18.18 - } \\
\text { Field: } \\
\text { 18.003-DNA } \\
\text { Laboratory } \\
\text { Setting } \\
\text { Value }\end{array}$} & \multirow[t]{4}{*}{$\begin{array}{l}\text { 8.18.3 } \\
\text { Table } 79\end{array}$} & \multirow[t]{4}{*}{$<$ Table 79 lists the valid values for DLS.> } & 1 & M & $\begin{array}{l}\text { 18.003- } \\
\text { UTY-Value }\end{array}$ & $\{$ Infoltem:1 in 18.003$\} \mathrm{MO}$ [ 1 to 4$]$ & & & & & $\mathrm{B}^{*}$ \\
\hline & & & 1 & $\mathrm{D}$ & $\begin{array}{l}\text { 18.003-LTY- } \\
\text { Value }\end{array}$ & $\{$ Infoltem:2 in 18.003$\} \mathrm{MO}[\mathrm{ASCII}(\mathrm{G}, \mathrm{I}, \mathrm{O}, \mathrm{U})]$ & & & & & $\mathrm{B}^{*}$ \\
\hline & & & 1 & $\mathrm{D}$ & $\begin{array}{l}\text { 18.003- } \\
\text { ACC-Value }\end{array}$ & $\begin{array}{l}<\text { Parse Infoltem: } 3 \text { in } 18.003 \text { into strings } \\
\text { separated by commas.> } \\
\text { Count(<strings }>\text { ) MO [1 to } 6] \\
\text { AND } \\
\text { ForEach(<string>) } \\
\{ \\
<\text { Number at start of string> MO [0 to 6, 255] } \\
\text { AND } \\
\text { IF < Number at start of string> EQ } 255 \\
\text { THEN Length(string) EQ } 3 \\
\text { ELSE IF <Number at start of string> EQ } 0 \\
\text { THEN Length(string) EQ } 1 \\
\text { ELSE } \\
<\text { Number at start of string followed by string of } \\
\text { N,M,D,O (non-repeating, length } 1 \text { to 4)> } \\
\}\end{array}$ & & & & & $\mathrm{T}$ \\
\hline & & & 1 & $\mathrm{D}$ & $\begin{array}{l}\text { NIEM- } \\
\text { 18.003- } \\
\text { ACC-Value }\end{array}$ & $\begin{array}{l}\text { ForEach (XEIm(biom:DNALaboratoryAccreditation } \\
\text { )) } \\
\{ \\
\{\text { XEIm(biom:DNALaboratoryAccreditationLevelCo } \\
\text { de)\} MO [0 to 6, 255] }\end{array}$ & & & & & $x$ \\
\hline
\end{tabular}




\begin{tabular}{|c|c|c|c|c|c|c|c|c|c|c|c|}
\hline Req. \# - ID & $\begin{array}{l}\text { Ref. in } \\
\text { Base } \\
\text { Std. }\end{array}$ & $\begin{array}{l}\text { Requirement } \\
\text { Summary }\end{array}$ & $\begin{array}{l}\mathrm{L} \\
\mathrm{e} \\
\mathrm{v} \\
\mathrm{e} \\
\mathrm{I}\end{array}$ & $\begin{array}{l}\mathrm{S} \\
\mathrm{t} \\
\mathrm{a} \\
\mathrm{t} \\
\mathrm{u} \\
\mathrm{s}\end{array}$ & $\begin{array}{l}\text { Assertion } \\
\text { ID }\end{array}$ & $\begin{array}{c}\text { Test } \\
\text { Assertion }\end{array}$ & $\begin{array}{l}\text { Test } \\
\text { Note }\end{array}$ & $\begin{array}{l}\text { Imp. } \\
\text { Support }\end{array}$ & $\begin{array}{l}\text { Supported } \\
\text { Range }\end{array}$ & $\begin{array}{l}\text { Test } \\
\text { Result }\end{array}$ & $\begin{array}{l}\text { Applicable } \\
\text { to }(T, X, B, \\
\left.B^{*}, \text { or } X^{*}\right)\end{array}$ \\
\hline
\end{tabular}

8.18: Record Type-18: DNA record

\begin{tabular}{|c|c|c|c|c|c|c|c|}
\hline & & & & & & $\begin{array}{l}\text { AND } \\
\text { IF } \\
\text { \{XEIm(biom:DNALaboratoryAccreditationLevelCo } \\
\text { de)\} EQ } 0 \text { OR } 255 \\
\text { THEN } \\
\text { Count(XEIm(biom:DNALaboratoryAccreditationSc } \\
\text { opeCode)) EQ } 0 \\
\text { ELSE } \\
\text { Bytes in } \\
\{\text { XEIm(biom:DNALaboratoryAccreditationScopeC } \\
\text { ode)\} MO ASCII(N,M,D,O) } \\
\}\end{array}$ & \\
\hline & & & 1 & 0 & $\begin{array}{l}\text { 18.003- } \\
\text { [NOO,POC, } \\
\text { ION]-Value }\end{array}$ & TRUE & $\mathrm{B}^{*}$ \\
\hline & & & 1 & 0 & $\begin{array}{l}\text { 18.003- } \\
\text { CSC-Value }\end{array}$ & $\begin{array}{l}\{\text { Infoltem:6 in } 18.003\} \\
\text { MO <Alpha2, Alpha3, and Numeric Values from } \\
\text { ISO-3166-1.> }\end{array}$ & $\mathrm{T}$ \\
\hline & & & 1 & 0 & $\begin{array}{l}\text { NIEM- } \\
\text { 18.003- } \\
\text { CSC-Value }\end{array}$ & $\begin{array}{l}\text { \{XEIm(biom:DNALaboratoryProcessingCountrylS } \\
\text { O3166Alpha2Code)\} } \\
\text { MO <Alpha2 Values from ISO-3166-1.> } \\
\text { OR } \\
\text { \{XEIm(biom:DNALaboratoryProcessingCountrylS } \\
\text { O3166Alpha3Code)\} } \\
\text { MO <Alpha3 Values from ISO-3166-1.> } \\
\text { OR } \\
\text { \{XEIm(biom:DNALaboratoryProcessingCountryls } \\
\text { O3166NumericCode)\} } \\
\text { MO <Numeric Values from ISO-3166-1.> }\end{array}$ & $\mathrm{x}$ \\
\hline $\begin{array}{l}\text { RT18.19- } \\
\text { Field: } \\
\text { 18.003-DNA }\end{array}$ & 8.18 .3 & $\begin{array}{l}\text { The second information item is the lab } \\
\text { type / LTY. It is mandatory if the value } \\
\text { for UTY is } 1 \text { or } 2 \text {. It is not entered }\end{array}$ & 1 & D & $\begin{array}{l}\text { 18.003- } \\
\text { Dependent } \\
\text { LTY }\end{array}$ & $\begin{array}{l}\text { Present(Infoltem:2 in 18.003) IFF } \\
\{\text { Infoltem:1 in 18.003\} } \mathrm{MO}[1,2]\end{array}$ & $\mathrm{B}^{*}$ \\
\hline $\begin{array}{l}\text { Laboratory } \\
\text { Setting } \\
\text { Dependent }\end{array}$ & & $\begin{array}{l}\text { otherwise. } \\
\text { The third information item is the } \\
\text { accreditation information / ACC. It is }\end{array}$ & 1 & D & $\begin{array}{l}18.003- \\
\text { Dependent } \\
\text { ACC }\end{array}$ & $\begin{array}{l}\text { Present(Infoltem:3 in 18.003) IFF } \\
\{\text { Infoltem:1 in } 18.003\} \mathrm{MO}[1,2]\end{array}$ & $\mathrm{B}^{*}$ \\
\hline
\end{tabular}




\begin{tabular}{|c|c|c|c|c|c|c|c|c|c|c|c|}
\hline Req. \# - ID & $\begin{array}{l}\text { Ref. in } \\
\text { Base } \\
\text { Std. }\end{array}$ & $\begin{array}{l}\text { Requirement } \\
\text { Summary }\end{array}$ & $\begin{array}{l}\text { L } \\
\text { e } \\
\text { v } \\
\text { e } \\
\text { I }\end{array}$ & $\begin{array}{l}\mathrm{S} \\
\mathrm{t} \\
\mathrm{a} \\
\mathrm{t} \\
\mathrm{u} \\
\mathrm{s}\end{array}$ & $\begin{array}{l}\text { Assertion } \\
\text { ID }\end{array}$ & $\begin{array}{c}\text { Test } \\
\text { Assertion }\end{array}$ & $\begin{array}{l}\text { Test } \\
\text { Note }\end{array}$ & $\begin{array}{l}\text { Imp. } \\
\text { Support }\end{array}$ & $\begin{array}{l}\text { Supported } \\
\text { Range }\end{array}$ & $\begin{array}{l}\text { Test } \\
\text { Result }\end{array}$ & $\begin{array}{l}\text { Applicable } \\
\text { to }(T, X, B, \\
\left.B^{*}, \text { or } X^{*}\right)\end{array}$ \\
\hline \multicolumn{12}{|c|}{ 8.18: Record Type-18: DNA record } \\
\hline Values & & $\begin{array}{l}\text { mandatory if the value for UTY is } 1 \text { or } 2 \text {. It } \\
\text { shall not be entered otherwise. }\end{array}$ & & & & & & & & & \\
\hline $\begin{array}{c}\text { RT18.20 - } \\
\text { Field: } \\
\text { 18.004- } \\
\text { Source } \\
\text { Agency } \\
\text { Value }\end{array}$ & 8.18 .4 & $\begin{array}{l}\text { This is a mandatory field. See Section } 7.6 \\
\text { for details. }\end{array}$ & 1 & M & $\begin{array}{l}\text { 18.004- } \\
\text { Value }\end{array}$ & <See Requirement ID: “Field: Source Agency”.> & $\mathrm{t}-2$ & & & & \\
\hline $\begin{array}{c}\text { RT18.21 - } \\
\text { Field: } \\
\text { 18.005- } \\
\text { Number Of } \\
\text { Analyses } \\
\text { Flag Value }\end{array}$ & 8.18 .5 & $<$ Table 79 lists the valid values for NAL.> & 1 & M & $\begin{array}{l}\text { 18.005- } \\
\text { Value }\end{array}$ & $\{18.005\}$ EQ 0 OR 1 & & & & & B \\
\hline \multirow{7}{*}{$\begin{array}{l}\text { RT18.22 - } \\
\text { Field: } \\
\text { 18.006- } \\
\text { Sample } \\
\text { Donor } \\
\text { Information } \\
\text { Value }\end{array}$} & \multirow[t]{7}{*}{8.18 .6} & \multirow[t]{7}{*}{$<$ Table 79 lists valid values for SDI.> } & 1 & M & $\begin{array}{l}\text { 18.006- } \\
\text { DSD-Value }\end{array}$ & $\{$ Infoltem:1 in 18.006$\} \mathrm{MO}$ [0 to 2] & & & & & $\mathrm{B}^{*}$ \\
\hline & & & 1 & 0 & $\begin{array}{l}\text { 18.006- } \\
\text { GID-Value }\end{array}$ & $\{$ Infoltem:2 in 18.006$\} \mathrm{MO}[\mathrm{ASCII}(\mathrm{M}, \mathrm{F}, \mathrm{U})]$ & & & & & $\mathrm{B}^{*}$ \\
\hline & & & 1 & 0 & $\begin{array}{l}\text { 18.006- } \\
\text { [DLC,DOB]- } \\
\text { Value }\end{array}$ & $\{$ Infoltem:3,4 in 18.006$\}$ MO [ValidLocalDate] & $\mathrm{t}-6$ & & & & $\mathrm{~T}$ \\
\hline & & & 1 & 0 & $\begin{array}{l}\text { NIEM- } \\
\text { 18.006- } \\
\text { [DLC,DOB]- } \\
\text { Value }\end{array}$ & $\begin{array}{l}\{\text { XEIm(nc:PersonBirthDate, } \\
\text { biom:DNADonorLastContactDate)\}MO [NIEM- } \\
\text { ValidLocalDate] }\end{array}$ & $\mathrm{t}-6$ & & & & $x$ \\
\hline & & & 1 & $\mathrm{O}$ & $\begin{array}{l}18.006- \\
{[E G P, \text { LLC]- }} \\
\text { Value }\end{array}$ & TRUE & & & & & $B^{*}$ \\
\hline & & & 1 & $\mathrm{D}$ & $\begin{array}{l}\text { 18.006- } \\
\text { DRA-Value }\end{array}$ & $\{$ Infoltem:6 in 18.006$\} \mathrm{MO}$ [0 to 2] & & & & & $\mathrm{B}^{*}$ \\
\hline & & & 1 & 0 & $\begin{array}{l}\text { 18.006- } \\
\text { SDS-Value }\end{array}$ & $\{$ Infoltem: 8 in 18.006$\} \mathrm{MO}[0$ to 2$]$ & & & & & $B^{*}$ \\
\hline $\begin{array}{l}\text { RT18.23 - } \\
\text { Field: } \\
\text { 18.006- }\end{array}$ & 8.18 .6 & $\begin{array}{l}\text { This information item shall be } \\
\text { entered only if } D S D=0 \text {. }\end{array}$ & 1 & $\mathrm{D}$ & $\begin{array}{l}\text { 18.006- } \\
\text { Dependent- } \\
\text { DSD }\end{array}$ & $\begin{array}{l}\text { Present(Infoltem:6 in 18.006) IFF \{Infoltem: } 1 \text { in } \\
\text { 18.006\} EQ } 0\end{array}$ & & & & & $\mathrm{~B}^{*}$ \\
\hline
\end{tabular}




\begin{tabular}{|c|c|c|c|c|c|c|c|c|c|c|c|}
\hline Req. \# - ID & $\begin{array}{l}\text { Ref. in } \\
\text { Base } \\
\text { Std. }\end{array}$ & $\begin{array}{l}\text { Requirement } \\
\text { Summary }\end{array}$ & $\begin{array}{l}\text { L } \\
\text { e } \\
\text { v } \\
\text { e } \\
\text { I }\end{array}$ & $\begin{array}{l}\mathrm{S} \\
\mathrm{t} \\
\mathrm{a} \\
\mathrm{t} \\
\mathrm{u} \\
\mathrm{s}\end{array}$ & $\begin{array}{l}\text { Assertion } \\
\text { ID }\end{array}$ & $\begin{array}{c}\text { Test } \\
\text { Assertion }\end{array}$ & $\begin{array}{l}\text { Test } \\
\text { Note }\end{array}$ & $\begin{array}{l}\text { Imp. } \\
\text { Support }\end{array}$ & $\begin{array}{l}\text { Supported } \\
\text { Range }\end{array}$ & $\begin{array}{l}\text { Test } \\
\text { Result }\end{array}$ & $\begin{array}{l}\text { Applicable } \\
\text { to }(\mathrm{T}, \mathrm{X}, \mathrm{B}, \\
\left.\mathrm{B}^{*} \text {, or } \mathrm{X}^{*}\right)\end{array}$ \\
\hline \multicolumn{12}{|c|}{ 8.18: Record Type-18: DNA record } \\
\hline \multicolumn{12}{|l|}{$\begin{array}{c}\text { Sample } \\
\text { Donor } \\
\text { Information } \\
\text { Dependent } \\
\text { Value }\end{array}$} \\
\hline $\begin{array}{l}\text { RT18.24 - } \\
\text { Field: } \\
\text { 18.007- } \\
\text { Claimed Or } \\
\text { Purported } \\
\text { Relationship } \\
\text { Value }\end{array}$ & 8.18 .7 & <Table 79 lists valid values for COPR.> & 1 & $\mathrm{D}$ & $\begin{array}{l}\text { 18.007- } \\
\text { Value }\end{array}$ & $\{18.007\} \mathrm{MO}[1$ to 7$]$ & & & & & B \\
\hline $\begin{array}{l}\text { RT18.25 - } \\
\text { Field: } \\
\text { 18.007- } \\
\text { Claimed Or } \\
\text { Purported } \\
\text { Relationship } \\
\text { Dependent } \\
\text { Value }\end{array}$ & 8.18 .7 & $\begin{array}{l}\text { This field is mandatory if the value for } \\
\text { DSD is equal to } 1 .\end{array}$ & 1 & $\mathrm{D}$ & $\begin{array}{l}\text { 18.007- } \\
\text { Dependent }\end{array}$ & $\begin{array}{l}\text { IF \{Infoltem:1 in } 18.006\} \text { EQ 1, Then Present } \\
(18.007)\end{array}$ & & & & & B \\
\hline $\begin{array}{l}\text { RT18.26 - } \\
\text { Field: } \\
\text { 18.008- } \\
\text { Validated } \\
\text { Relationship } \\
\text { Value }\end{array}$ & 8.18 .8 & <Table 79 lists valid values for VRS.> & 1 & $\mathrm{D}$ & $\begin{array}{l}\text { 18.008- } \\
\text { Value }\end{array}$ & $\{18.008\} \mathrm{MO}[1$ to 7$]$ & & & & & B \\
\hline $\begin{array}{l}\text { RT18.27 - } \\
\text { Field: } \\
\text { 18.008- } \\
\text { Validated } \\
\text { Relationship } \\
\text { Dependent } \\
\text { Value }\end{array}$ & 8.18 .8 & $\begin{array}{l}\text { This field is optional and... is only filled in if } \\
D S D=1 .\end{array}$ & 1 & $\mathrm{D}$ & $\begin{array}{l}\text { 18.008- } \\
\text { Dependent }\end{array}$ & $\begin{array}{l}\text { IF Present (18.008), Then }\{\text { Infoltem:1 in } 18.006\} \\
\text { EQ } 1\end{array}$ & & & & & B \\
\hline $\begin{array}{l}\text { RT18.28 - } \\
\text { Field: }\end{array}$ & 8.18 .9 & <Table 79 lists valid values for PED.> & 1 & - & $\begin{array}{l}\text { 18.009- } \\
\text { [PID, PMI, }\end{array}$ & TRUE & & & & & $\mathrm{B}^{*}$ \\
\hline
\end{tabular}




\begin{tabular}{|c|c|c|c|c|c|c|c|c|c|c|c|}
\hline Req. \# - ID & $\begin{array}{l}\text { Ref. in } \\
\text { Base } \\
\text { Std. }\end{array}$ & $\begin{array}{l}\text { Requirement } \\
\text { Summary }\end{array}$ & $\begin{array}{l}\text { L } \\
\text { e } \\
\text { v } \\
\text { e } \\
\text { I }\end{array}$ & $\begin{array}{l}\mathrm{s} \\
\mathrm{t} \\
\mathrm{a} \\
\mathrm{t} \\
\mathrm{u} \\
\mathrm{s}\end{array}$ & $\begin{array}{l}\text { Assertion } \\
\text { ID }\end{array}$ & $\begin{array}{c}\text { Test } \\
\text { Assertion }\end{array}$ & $\begin{array}{l}\text { Test } \\
\text { Note }\end{array}$ & $\begin{array}{c}\text { Imp. } \\
\text { Support }\end{array}$ & $\begin{array}{l}\text { Supported } \\
\text { Range }\end{array}$ & $\begin{array}{l}\text { Test } \\
\text { Result }\end{array}$ & $\begin{array}{l}\text { Applicable } \\
\text { to }(T, X, B \text {, } \\
\left.B^{*}, \text { or } X^{*}\right)\end{array}$ \\
\hline \multicolumn{12}{|c|}{ 8.18: Record Type-18: DNA record } \\
\hline \multirow{2}{*}{$\begin{array}{l}\text { 18.009- } \\
\text { Pedigree } \\
\text { Information } \\
\text { Value }\end{array}$} & & & & & $\begin{array}{l}\text { SID, FID, } \\
\text { MID, PCM]- } \\
\text { Value }\end{array}$ & & & & & & \\
\hline & & & 1 & M & $\begin{array}{c}\text { 18.009- } \\
\text { PMS-Value }\end{array}$ & $\{$ Infoltem:3 in 18.009$\} \mathrm{MO}[\mathrm{ASCII}(\mathrm{K}, \mathrm{U})]$ & & & & & $\mathrm{B}^{*}$ \\
\hline $\begin{array}{l}\text { RT18.29 - } \\
\text { Field: }\end{array}$ & \multirow[t]{2}{*}{8.18 .10} & \multirow[t]{2}{*}{$<$ Table 79 lists valid values for STY.> } & 1 & M & $\begin{array}{l}\text { 18.010- } \\
\text { SCT-Value }\end{array}$ & $\{$ Infoltem:1 in 18.010$\} \mathrm{MO}$ [0 to 11$]$ & & & & & $\mathrm{B}^{*}$ \\
\hline $\begin{array}{l}\text { 18.010- } \\
\text { Sample Type } \\
\text { Value }\end{array}$ & & & 1 & 0 & $\begin{array}{l}\text { 18.010- } \\
\text { SMO-Value }\end{array}$ & $\{$ Infoltem:2 in 18.010$\} \mathrm{MO}$ [ASCII(NS, WB, BP)] & & & & & $\mathrm{B}^{*}$ \\
\hline $\begin{array}{l}\text { RT18.30 - } \\
\text { Field: } \\
\text { 18.011- } \\
\text { Sample } \\
\text { Typing } \\
\text { Information } \\
\text { Value }\end{array}$ & 8.18 .11 & $<$ Table 79 lists valid values for STI.> & 1 & M & $\begin{array}{l}\text { 18.011- } \\
\text { Value }\end{array}$ & $\begin{array}{l}\text { ForEach(SubField in 18.011) } \\
\{ \\
\{\text { Infoltem:1 in SubField }\} \text { MO [0 to 4] } \\
\}\end{array}$ & & & & & $\mathrm{B}^{*}$ \\
\hline $\begin{array}{c}\text { RT18.31 - } \\
\text { Field: } \\
\text { 18.012- } \\
\text { Sample } \\
\text { Collection } \\
\text { Method } \\
\text { Value }\end{array}$ & 8.18 .12 & $<$ Table 79 lists valid values for SCM.> & 1 & 0 & $\begin{array}{l}\text { 18.012- } \\
\text { Value }\end{array}$ & TRUE & & & & & B \\
\hline \multirow{2}{*}{$\begin{array}{l}\text { RT18.32 - } \\
\text { Field: } \\
\text { 18.013- } \\
\text { Sample } \\
\text { Collection } \\
\text { Date Value }\end{array}$} & \multirow[t]{2}{*}{8.18 .13} & \multirow[t]{2}{*}{$<$ Table 79 lists valid values for SCD.> } & 1 & M & $\begin{array}{l}\text { 18.013- } \\
\text { Value }\end{array}$ & $\{18.013\}$ MO [ValidUTC/GMT] & $\mathrm{t}-6$ & & & & $\mathrm{~T}$ \\
\hline & & & 1 & M & $\begin{array}{l}\text { NIEM- } \\
\text { 18.013- } \\
\text { Value }\end{array}$ & $\{18.013\}$ MO [NIEM-ValidUTC/GMT] & $\mathrm{t}-6$ & & & & $\mathrm{x}$ \\
\hline \multirow{2}{*}{$\begin{array}{c}\text { RT18.33 - } \\
\text { Field: } \\
\text { 18.014- } \\
\text { Profile } \\
\text { Storage Date }\end{array}$} & \multirow[t]{2}{*}{8.18 .14} & \multirow[t]{2}{*}{$<$ Table 79 lists valid values for PSD.> } & 1 & M & $\begin{array}{l}\text { 18.014- } \\
\text { Value }\end{array}$ & $\{18.014\} \mathrm{MO}$ [ValidUTC/GMT] & $\mathrm{t}-6$ & & & & $\mathrm{~T}$ \\
\hline & & & 1 & M & $\begin{array}{l}\text { NIEM- } \\
\text { 18.014- } \\
\text { Value }\end{array}$ & $\{18.014\}$ MO [NIEM-ValidUTC/GMT] & $\mathrm{t}-6$ & & & & $x$ \\
\hline
\end{tabular}




\begin{tabular}{|c|c|c|c|c|c|c|c|c|c|c|c|}
\hline Req. \# - ID & $\begin{array}{l}\text { Ref. in } \\
\text { Base } \\
\text { Std. }\end{array}$ & $\begin{array}{l}\text { Requirement } \\
\text { Summary }\end{array}$ & $\begin{array}{l}\text { L } \\
\text { e } \\
\text { v } \\
\text { e } \\
\text { I }\end{array}$ & \begin{tabular}{l|l|}
$\mathrm{s}$ & \\
$\mathrm{t}$ & \\
$\mathrm{a}$ & \\
$\mathrm{t}$ & $\mathrm{u}$ \\
$\mathrm{u}$
\end{tabular} & $\begin{array}{l}\text { Assertion } \\
\text { ID }\end{array}$ & $\begin{array}{c}\text { Test } \\
\text { Assertion }\end{array}$ & $\begin{array}{l}\text { Test } \\
\text { Note }\end{array}$ & $\begin{array}{l}\text { Imp. } \\
\text { Support }\end{array}$ & $\begin{array}{l}\text { Supported } \\
\text { Range }\end{array}$ & $\begin{array}{l}\text { Test } \\
\text { Result }\end{array}$ & $\begin{array}{l}\text { Applicable } \\
\text { to }(T, X, B \text {, } \\
\left.B^{*} \text {, or } X^{*}\right)\end{array}$ \\
\hline \multicolumn{12}{|c|}{ 8.18: Record Type-18: DNA record } \\
\hline \multicolumn{12}{|l|}{ Value } \\
\hline \multirow{3}{*}{$\begin{array}{l}\text { RT18.34 - } \\
\quad \text { Field: } \\
\text { 18.015-DNA } \\
\text { Profile Data } \\
\quad \text { Value }\end{array}$} & \multirow[t]{3}{*}{8.18 .15} & \multirow[t]{3}{*}{ <Table 79 lists valid values for DPD.> } & 1 & M & $\begin{array}{l}\text { 18.015- } \\
\text { PTP-Value }\end{array}$ & $\{$ Infoltem: 1 in 18.015$\} \mathrm{MO}[0,1]$ & & & & & $\mathrm{B}^{*}$ \\
\hline & & & 1 & 0 & $\begin{array}{l}\text { 18.015- } \\
\text { RES-Value }\end{array}$ & $\{$ Infoltem:2 in 18.015$\} \mathrm{MO}[0,10]$ & & & & & $\mathrm{B}^{*}$ \\
\hline & & & 1 & - & $\begin{array}{l}\text { 18.015- } \\
\text { [PRF,SUP,D } \\
\text { PC]-Value }\end{array}$ & TRUE & & & & & $\mathrm{B}^{*}$ \\
\hline \multirow{5}{*}{$\begin{array}{l}\text { RT18.35- } \\
\text { Field: } \\
\text { 18.016- } \\
\text { Autosomal } \\
\text { STR, X-STR } \\
\text { and Y-STR } \\
\text { Value }\end{array}$} & \multirow[t]{5}{*}{8.18 .16} & \multirow[t]{5}{*}{$\begin{array}{l}<\text { Table } 79 \text { lists the value constraints for } \\
\text { STR.> }\end{array}$} & 1 & M & $\begin{array}{l}\text { 18.016- } \\
\text { DST-Value }\end{array}$ & $\begin{array}{l}\text { ForEach(SubField in } 18.016) \\
\{ \\
\{\text { Infoltem:1 in SubField }\} \text { MO }[0,1,2] \\
\}\end{array}$ & & & & & $B^{*}$ \\
\hline & & & 1 & M & $\begin{array}{l}\text { 18.016- } \\
\text { DLR-Value }\end{array}$ & $\begin{array}{l}\text { ForEach(SubField in 18.016) } \\
\{ \\
\{\text { Infoltem:2 in SubField }\} \text { MO [1 to 200] } \\
\}\end{array}$ & & & & & $\mathrm{B}^{*}$ \\
\hline & & & 1 & M & $\begin{array}{l}\text { 18.016- } \\
\text { [ALL, LAI, } \\
\text { PCDT]- } \\
\text { Value }\end{array}$ & $\begin{array}{l}\text { ForEach(SubField in 18.016) } \\
\{ \\
\{\text { Infoltem:3,4,5 in SubField }\} \text { MO }[0,1] \\
\}\end{array}$ & & & & & $\mathrm{B}^{*}$ \\
\hline & & & 1 & D & $\begin{array}{l}\text { 18.016- } \\
\text { [AL1,AL2,AL } \\
\text { 3]-Value }\end{array}$ & $\begin{array}{l}\text { ForEach(SubField in 18.016) } \\
\{ \\
\{\text { Infoltem:6,7,8 in SubField }\} \text { GTE } 0 \\
\text { AND } \\
\text { IF Present(ASCII(.) in Infoltem: } 6,7,8 \text { in SubField) } \\
\text { Then Count(<number digits following> ASCII(.) in } \\
\text { Infoltem: } 6,7,8 \text { in SubField) EQ } 1 \\
\}\end{array}$ & $\mathrm{t}-18$ & & & & $B^{*}$ \\
\hline & & & 1 & - & $\begin{array}{c}18.016- \\
\text { [BID,ECR,LC } \\
\text { R,KNM,KM }\end{array}$ & TRUE & & & & & $\mathrm{B}^{*}$ \\
\hline
\end{tabular}




\begin{tabular}{|c|c|c|c|c|c|c|c|c|c|c|c|}
\hline Req. \# - ID & $\begin{array}{l}\text { Ref. in } \\
\text { Base } \\
\text { Std. }\end{array}$ & $\begin{array}{l}\text { Requirement } \\
\text { Summary }\end{array}$ & $\begin{array}{l}\text { L } \\
\text { e } \\
\text { v } \\
\text { e } \\
\text { I }\end{array}$ & $\begin{array}{l}\mathrm{S} \\
\mathrm{t} \\
\mathrm{a} \\
\mathrm{t} \\
\mathrm{u} \\
\mathrm{s}\end{array}$ & $\begin{array}{l}\text { Assertion } \\
\text { ID }\end{array}$ & $\begin{array}{c}\text { Test } \\
\text { Assertion }\end{array}$ & $\begin{array}{l}\text { Test } \\
\text { Note }\end{array}$ & $\begin{array}{l}\text { Imp. } \\
\text { Support }\end{array}$ & $\begin{array}{l}\text { Supported } \\
\text { Range }\end{array}$ & $\begin{array}{c}\text { Test } \\
\text { Result }\end{array}$ & $\begin{array}{l}\text { Applicable } \\
\text { to }(T, X, B \text {, } \\
\left.B^{*} \text {, or } X^{*}\right)\end{array}$ \\
\hline \multicolumn{12}{|c|}{ 8.18: Record Type-18: DNA record } \\
\hline & & & & & $\begin{array}{l}\text { F,KDS]- } \\
\text { Value }\end{array}$ & & & & & & \\
\hline & & & 1 & M & $\begin{array}{l}\text { 18.016-KID- } \\
\text { Value }\end{array}$ & $\begin{array}{l}\text { ForEach(SubField in 18.016) } \\
\{ \\
\{\text { Infoltem: } 12 \text { in SubField\} MO [0 to 999] } \\
\}\end{array}$ & & & & & $\mathrm{B}^{*}$ \\
\hline \multirow[t]{3}{*}{$\begin{array}{l}\text { RT18.36- } \\
\quad \text { Field: } \\
\text { 18.016- } \\
\text { Autosomal } \\
\text { STR, X-STR } \\
\text { and Y-STR } \\
\text { Dependent } \\
\text { Value }\end{array}$} & & $\begin{array}{l}\text { "The sixth information item shall have a } \\
\text { value if ALL is } 1 \text {. It shall be empty if } \\
\text { ALL is } 0 . \text {." } \\
\text { "The seventh information item is } \\
\text { conditional upon the value of ALL being } 1 . \\
\text { It may appear only if AL1 is used." } \\
\text { "The eighth information item is optional } \\
\text { but shall not appear unless ALL }=1 \text {. The }\end{array}$ & 1 & D & $\begin{array}{l}\text { 18.016- } \\
\text { Dependent- } \\
\quad \text { AL1 }\end{array}$ & $\begin{array}{l}\text { ForEach(SubField in 18.016) } \\
\{ \\
\text { IF }\{\text { Infoltem: } 3 \text { in SubField }\} \text { EQ 1, Then } \\
\text { Present(Infoltem:6 in SubField) } \\
\text { AND } \\
\text { IF }\{\text { Infoltem: } 3 \text { in SubField }\} \text { EQ 0, Then NOT } \\
\text { Present(Infoltem:6 in SubField) } \\
\}\end{array}$ & & & & & $\mathrm{B}^{*}$ \\
\hline & & $\begin{array}{l}\text { information item allele call } 3 / \text { AL3 } \\
\text { shall only appear if information items AL1 } \\
\text { and AL2 are present" } \\
\text { "KNM shall be entered if KID }=0 \text { " } \\
\text { "KMF shall be entered if KID }=0 \text { " } \\
\text { "KDS shall be entered if KID }=0 \text { " }\end{array}$ & 1 & $\mathrm{D}$ & $\begin{array}{l}\text { 18.016- } \\
\text { Dependent- } \\
\quad \text { AL2 }\end{array}$ & $\begin{array}{l}\text { ForEach(SubField in 18.016) } \\
\{ \\
\text { IF NOT Present(Infoltem:6 in SubField) Then NOT } \\
\text { Present(Infoltem: } 7 \text { in SubField) } \\
\text { ELSE } \\
\text { IF }\{\text { Infoltem: } 3 \text { in SubField }\} \text { EQ } 1 \text {, Then } \\
\text { Present(Infoltem: } 7 \text { in SubField) } \\
\text { AND } \\
\text { IF \{Infoltem: } 3 \text { in SubField }\} \text { EQ 0, Then NOT } \\
\text { Present(Infoltem:7 in SubField) } \\
\text { \} }\end{array}$ & & & & & $\mathrm{B}^{*}$ \\
\hline & & & 1 & $\mathrm{D}$ & $\begin{array}{l}\text { 18.016- } \\
\text { Dependent- } \\
\text { AL3 }\end{array}$ & $\begin{array}{l}\text { ForEach(SubField in 18.016) } \\
\{ \\
\text { IF NOT Present(Infoltem:6,7 in SubField) Then } \\
\text { NOT Present(Infoltem:8 in SubField) } \\
\text { ELSE } \\
\text { IF }\{\text { Infoltem: } 3 \text { in SubField }\} \text { EQ 1, Then } \\
\text { Present(Infoltem:8 in SubField) } \\
\text { AND } \\
\text { IF }\{\text { Infoltem: } 3 \text { in SubField }\} \text { EQ 0, Then NOT } \\
\text { Present(Infoltem:8 in SubField) }\end{array}$ & & & & & $\mathrm{B}^{*}$ \\
\hline
\end{tabular}




\begin{tabular}{|c|c|c|c|c|c|c|c|c|c|c|c|}
\hline Req. \# - ID & $\begin{array}{l}\text { Ref. in } \\
\text { Base } \\
\text { Std. }\end{array}$ & $\begin{array}{l}\text { Requirement } \\
\text { Summary }\end{array}$ & $\begin{array}{l}\text { L } \\
\text { e } \\
\text { v } \\
\text { e } \\
\text { I }\end{array}$ & $\begin{array}{l}\mathrm{s} \\
\mathrm{t} \\
\mathrm{a} \\
\mathrm{t} \\
\mathrm{u} \\
\mathrm{s}\end{array}$ & $\begin{array}{l}\text { Assertion } \\
\text { ID }\end{array}$ & $\begin{array}{c}\text { Test } \\
\text { Assertion }\end{array}$ & $\begin{array}{l}\text { Test } \\
\text { Note }\end{array}$ & $\begin{array}{l}\text { Imp. } \\
\text { Support }\end{array}$ & $\begin{array}{l}\text { Supported } \\
\text { Range }\end{array}$ & $\begin{array}{c}\text { Test } \\
\text { Result }\end{array}$ & $\begin{array}{l}\text { Applicable } \\
\text { to }(T, X, B, \\
\left.B^{*}, \text { or } X^{*}\right)\end{array}$ \\
\hline \multicolumn{12}{|c|}{ 8.18: Record Type-18: DNA record } \\
\hline & & & & & & \} & & & & & \\
\hline & & & 1 & $\mathrm{D}$ & $\begin{array}{c}\text { 18.016- } \\
\text { Dependent- } \\
\text { [KNM, } \\
\text { KMF, KDS] }\end{array}$ & $\begin{array}{l}\text { ForEach(SubField in 18.016) } \\
\{ \\
\text { IF }\{\text { Infoltem: } 12 \text { in SubField }\} \text { EQ } 0 \text { Then } \\
\text { Present(Infoltem:13,14,15 in SubField) } \\
\}\end{array}$ & & & & & $\mathrm{B}^{*}$ \\
\hline \multirow{3}{*}{$\begin{array}{l}\text { RT18.37- } \\
\text { Field: } \\
\text { 18.017- } \\
\text { Mitochondri } \\
\text { al DNA Data } \\
\text { Value }\end{array}$} & 8.18 .17 & $\begin{array}{l}<\text { Table } 79 \text { lists the value constraints for } \\
\text { DMD.> }\end{array}$ & 1 & M & $\begin{array}{l}\text { 18.017- } \\
\text { [MT1,MT2] } \\
\text {-Value }\end{array}$ & $\begin{array}{l}\text { All(Bytes(Infoltem:1,2 in 18.017)) } \\
\text { MO [ASCII(R,Y,M,K,S,W,H,B,V,D,N,-,A,G,C,T)] }\end{array}$ & & & & & $\mathrm{B}^{*}$ \\
\hline & & & 1 & M & $\begin{array}{c}\text { 18.017- } \\
\text { [BSP,BCA,B } \\
\text { CG,BCC,BCT } \\
\text { ]-Value }\end{array}$ & $\begin{array}{l}\{\text { Infoltem:3,5,6,7,8 in } 18.017\} \text { GTE } 0 \text { AND MO } \\
\text { [Integers] }\end{array}$ & & & & & $\mathrm{B}^{*}$ \\
\hline & & & 2 & M & $\begin{array}{l}\text { 18.017- } \\
\text { BEP-Value }\end{array}$ & $\begin{array}{l}\{\text { Infoltem:4 in } 18.017\} \text { GT }\{\text { Infoltem:3 in } 18.017\} \\
\text { GT O AND MO[Integers] }\end{array}$ & & & & & $B^{*}$ \\
\hline $\begin{array}{l}\text { RT18.38 - } \\
\text { Field: } \\
\text { 18.018-DNA } \\
\text { User- } \\
\text { Defined } \\
\text { Profile Data } \\
\text { Value }\end{array}$ & 8.18 .18 & $\begin{array}{l}<\text { Table } 79 \text { lists the value constraints for } \\
\text { UDP.> }\end{array}$ & 1 & M & $\begin{array}{l}\text { 18.018- } \\
\text { Value }\end{array}$ & TRUE & & & & & B \\
\hline $\begin{array}{l}\text { RT18.39 - } \\
\text { Field: } \\
\text { 18.019- } \\
\text { Electrophero } \\
\text { gram } \\
\text { Description } \\
\text { Value }\end{array}$ & 8.18 .19 & $\begin{array}{l}<\text { Table } 79 \text { lists the value constraints for } \\
\text { EPD.> }\end{array}$ & 1 & - & $\begin{array}{l}\text { 18.019- } \\
\text { Value }\end{array}$ & TRUE & & & & & $\mathrm{B}^{*}$ \\
\hline $\begin{array}{l}\text { RT18.40 - } \\
\text { Field: } \\
\text { 18.020-DNA } \\
\text { Genotype } \\
\text { Distribution } \\
\text { Value }\end{array}$ & 8.18 .20 & $\begin{array}{l}<\text { Table } 79 \text { lists the value constraints for } \\
\text { DGD.> }\end{array}$ & 1 & 0 & $\begin{array}{l}18.020- \\
\text { Value }\end{array}$ & $\{18.020\}$ EQ 0 OR 1 & & & & & B \\
\hline
\end{tabular}




\begin{tabular}{|c|c|c|c|c|c|c|c|c|c|c|c|}
\hline Req. \# - ID & $\begin{array}{l}\text { Ref. in } \\
\text { Base } \\
\text { Std. }\end{array}$ & $\begin{array}{l}\text { Requirement } \\
\text { Summary }\end{array}$ & $\begin{array}{l}\text { L } \\
\text { e } \\
\text { v } \\
\text { e } \\
\text { I }\end{array}$ & $\begin{array}{l}\mathrm{s} \\
\mathrm{t} \\
\mathrm{a} \\
\mathrm{t} \\
\mathrm{u} \\
\mathrm{s}\end{array}$ & $\begin{array}{l}\text { Assertion } \\
\text { ID }\end{array}$ & $\begin{array}{c}\text { Test } \\
\text { Assertion }\end{array}$ & $\begin{array}{l}\text { Test } \\
\text { Note }\end{array}$ & $\begin{array}{l}\text { Imp. } \\
\text { Support }\end{array}$ & $\begin{array}{l}\text { Supported } \\
\text { Range }\end{array}$ & $\begin{array}{l}\text { Test } \\
\text { Result }\end{array}$ & $\begin{array}{l}\text { Applicable } \\
\text { to }(T, X, B \text {, } \\
\left.B^{*} \text {, or } X^{*}\right)\end{array}$ \\
\hline \multicolumn{12}{|c|}{ 8.18: Record Type-18: DNA record } \\
\hline \multirow{3}{*}{$\begin{array}{l}\text { RT18.41 - } \\
\text { Field: } \\
\text { 18.021- DNA } \\
\text { Genotype } \\
\text { Allele Pair } \\
\text { Value }\end{array}$} & \multirow[t]{3}{*}{8.18 .21} & \multirow[t]{3}{*}{$\begin{array}{l}<\text { Table } 79 \text { lists the value constraints for } \\
\text { GAP.> }\end{array}$} & 1 & M & $\begin{array}{l}\text { 18.021- } \\
\text { GLR-Value }\end{array}$ & $\begin{array}{l}\text { ForEach(SubField in 18.021) } \\
\{ \\
\{\text { Infoltem: } 1 \text { in SubField }\} \text { MO [1 to 200] } \\
\}\end{array}$ & & & & & $B^{*}$ \\
\hline & & & 1 & M & $\begin{array}{l}\text { 18.021- } \\
\text { ALP-Value }\end{array}$ & 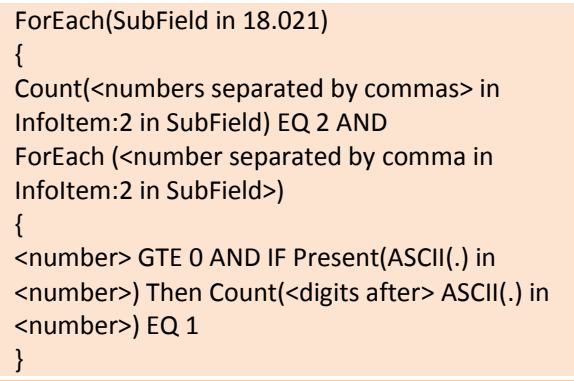 & & & & & $\mathrm{B}^{*}$ \\
\hline & & & 1 & M & $\begin{array}{l}\text { 18.021- } \\
\text { GNW-Value }\end{array}$ & $\begin{array}{l}\text { ForEach(SubField in 18.021) } \\
\{ \\
\text { \{Infoltem:3 in SubField }\} \text { GTE } 0 \text { AND LTE } 1 \\
\text { AND } \\
\text { IF Present(ASCII(.) in Infoltem: } 3 \text { in SubField) Then } \\
\text { Count(<digits after> ASCII(.) in Infoltem:3 in } \\
\text { SubField) MO [1 to 3] } \\
\}\end{array}$ & & & & & $\mathrm{B}^{*}$ \\
\hline $\begin{array}{c}\text { RT18.42 - } \\
\text { Field: } \\
\text { 18.022- } \\
\text { Comment } \\
\text { Value }\end{array}$ & 8.18 .22 & $\begin{array}{l}<\text { Table } 79 \text { lists the value constraints for } \\
\text { COM.> }\end{array}$ & 1 & $\mathrm{O}$ & $\begin{array}{l}\text { 18.022- } \\
\text { Value }\end{array}$ & TRUE & & & & & B \\
\hline $\begin{array}{c}\text { RT18.43 - } \\
\text { Field: } 18.023 \\
\text { Electrophero } \\
\text { gram Ladder } \\
\text { Value }\end{array}$ & 8.18 .23 & $\begin{array}{l}<\text { Table } 79 \text { lists the value constraints for } \\
\text { EPL.> }\end{array}$ & 1 & M & $\begin{array}{l}\text { 18.023- } \\
\text { Value }\end{array}$ & TRUE & & & & & $\mathrm{B}^{*}$ \\
\hline $\begin{array}{l}\text { RT18.44 - } \\
\text { Field: } 18.200\end{array}$ & 8.18 .24 & User Defined Fields & - & - & $\begin{array}{l}18.200 \text { to } \\
18.900-\end{array}$ & TRUE & & & & & B \\
\hline
\end{tabular}




\begin{tabular}{|c|c|c|c|c|c|c|c|c|c|c|c|}
\hline Req. \# - ID & $\begin{array}{l}\text { Ref. in } \\
\text { Base } \\
\text { Std. }\end{array}$ & $\begin{array}{l}\text { Requirement } \\
\text { Summary }\end{array}$ & $\begin{array}{l}\text { L } \\
\text { e } \\
\text { v } \\
\text { e } \\
\text { I }\end{array}$ & $\begin{array}{l}\mathrm{S} \\
\mathrm{t} \\
\mathrm{a} \\
\mathrm{t} \\
\mathrm{u} \\
\mathrm{s}\end{array}$ & $\begin{array}{l}\text { Assertion } \\
\text { ID }\end{array}$ & $\begin{array}{c}\text { Test } \\
\text { Assertion }\end{array}$ & $\begin{array}{l}\text { Test } \\
\text { Note }\end{array}$ & $\begin{array}{l}\text { Imp. } \\
\text { Support }\end{array}$ & $\begin{array}{l}\text { Supported } \\
\text { Range }\end{array}$ & $\begin{array}{l}\text { Test } \\
\text { Result }\end{array}$ & $\begin{array}{l}\text { Applicable } \\
\text { to }(T, X, B \text {, } \\
\left.B^{*} \text {, or } X^{*}\right)\end{array}$ \\
\hline \multicolumn{12}{|c|}{ 8.18: Record Type-18: DNA record } \\
\hline $\begin{array}{l}\text { to } 18.900- \\
\text { User } \\
\text { Defined } \\
\text { Value }\end{array}$ & & & & & Value & & & & & & \\
\hline $\begin{array}{l}\text { RT18.45 - } \\
\text { Field: } \\
\text { 18.902- } \\
\text { Annotated } \\
\text { Information } \\
\text { Value }\end{array}$ & 8.18 .25 & $\begin{array}{l}\text { This is an optional field, listing the } \\
\text { operations performed on the original } \\
\text { source in order to prepare it for inclusion } \\
\text { in a biometric record type. See Section } \\
\text { 7.4.1. }\end{array}$ & & 0 & $\begin{array}{l}\text { 18.902- } \\
\text { [GMT, NAV, } \\
\text { OWN, } \\
\text { PRO]-Value }\end{array}$ & <See Requirement ID: "Field: xx.902-ANN" >. & $\mathrm{t}-2$ & & & & \\
\hline $\begin{array}{c}\text { RT18.46 - } \\
\text { Field: } \\
\text { 18.993- } \\
\text { Source } \\
\text { Agency } \\
\text { Name } \\
\text { Value }\end{array}$ & 8.18 .26 & $\begin{array}{l}\text { This is an optional field. It may contain up } \\
\text { to } 125 \text { Unicode characters. }\end{array}$ & & 0 & $\begin{array}{l}\text { 18.993- } \\
\text { Value }\end{array}$ & $\begin{array}{l}\text { <See Requirment ID: "Field: Source Agency } \\
\underline{\text { Name". }}\end{array}$ & $\mathrm{t}-2$ & & & & \\
\hline $\begin{array}{l}\text { RT18.47 - } \\
\text { Field: } \\
\text { 18.995- } \\
\text { Associated } \\
\text { Context } \\
\text { Value }\end{array}$ & 8.18 .27 & See Section 7.3.3 & & 0 & $\begin{array}{l}18.995- \\
\text { [ACN, ASP]- } \\
\quad \text { Value }\end{array}$ & $\begin{array}{l}\text { <See Requirement IDs: "Field: xx.995-ASC" and } \\
\text { "Field: xx.995-ASC-ACN" and } \\
\text { "Field: xx.995-ASC-ASP">. }\end{array}$ & $\mathrm{t}-2$ & & & & \\
\hline $\begin{array}{l}\text { RT18.48 - } \\
\text { Field: } \\
\text { 18.998- } \\
\text { Geographic } \\
\text { Sample } \\
\text { Acquisition } \\
\text { Location } \\
\text { Value }\end{array}$ & 8.18 .28 & See Section 7.7.3 & & 0 & $\begin{array}{c}\text { 18.998- } \\
\text { [UTE, } \\
\text { LTD,LTM, } \\
\text { LTS, LGD, } \\
\text { LGM, LGS, } \\
\text { ELE, GDC, } \\
\text { GCM, GCE, } \\
\text { GCN, GRT, } \\
\text { OSI, OCV]- } \\
\text { Value }\end{array}$ & $\begin{array}{l}\text { <See Requirement IDs: "Field: Geographic", } \\
\text { "Field: Geographic", "Field: Geographic-Subfield } \\
\underline{\underline{1} \text { " through "Field: Geographic-Values-SubField }} \\
\underline{15} \text { " >. }\end{array}$ & $\mathrm{t}-2$ & & & & \\
\hline
\end{tabular}




\section{B.2 Test Notes}

The following test notes provide clarification of the assertion text provided in the Test Assertion column of Table B.1. Only test notes relevant to Type 18 Record Type are included:

$\mathrm{t}-2$. The assertions for this requirement are listed in another section of the table or in another table of NIST SP 500-295 as described in the "Test Assertion" column.

t-6. UTC has replaced GMT. Date and time are defined in section 7.7.2 of the standard. The set of values ValidUTC/GMT is described in section 7.7.2.2 of the standard and is always less than the current date and time. ValidUTC/GMT is in the form YYYYMMDDHHMMSSZ; NIEM-ValidUTC/GMT is in the form YYYY-MM-DDThh:mm:ssZ. The ValidLocalDate is in the form YYYYMMDD; NIEM-ValidLocalDate is in the form YYYY-MM-DD, YYYY-MM, or YYYY.

t-18. Table 79 in NIST SP 500-290 lists possible values as 'integer $>0$; or real number with one digit to the right of the decimal'. Negative integer values are a subset of real numbers, and would conflict with the requirement "integer $>0$ ". For the pertinent test assertion in the table, negative values are not considered part of the valid value range. 